\title{
High-Throughput Screening and Analysis of Genes of Xanthomonas citri subsp. citri Involved in Citrus Canker Symptom Development
}

\author{
Qing Yan and Nian Wang \\ Citrus Research and Education Center, Department of Microbiology and Cell Science, University of Florida, 700 Experiment \\ Station Road, Lake Alfred, FL 33850, U.S.A.
}

Submitted 18 May 2011. Accepted 29 August 2011

Citrus canker is caused by Xanthomonas citri subsp. citri and is one of the most devastating diseases on citrus plants. To investigate the virulence mechanism of this pathogen, a mutant library of strain 306 containing approximately 22,000 mutants was screened for virulence-deficient mutants in grapefruit (Citrus paradise). Eighty-two genes were identified that contribute to citrus canker symptom development caused by $X$. citri subsp. citri. Among the 82 identified genes, 23 genes were classified as essential genes, as mutation of these genes caused severe reduction of bacterial growth in M9 medium. The remaining 59 genes were classified as putative virulence-related genes that include 32 previously reported virulence-related genes and 27 novel genes. The 32 known virulence-related genes include genes that are involved in the type III secretion system (T3SS) and T3SS effectors, the quorum-sensing system, extracellular polysaccharide and lipopolysaccharide synthesis, and general metabolic pathways. The contribution to pathogenesis by nine genes (pthA4, trpG, trpC, purD, hrpM, peh1, XAC1230, XAC1548, and XAC3049) was confirmed by complementation assays. We further validated the mutated genes and their phenotypes by analyzing the EZ-Tn5 insertion copy number using Southern blot analysis. In conclusion, we have significantly advanced our understanding of the putative genetic determinants of the virulence mechanism of $X$. citri subsp. citri by identifying 59 putative virulence-related genes, including 27 novel genes.

Plant pathogenic bacteria of the genus Xanthomonas cause a variety of diseases in economically important crop plants worldwide (Subramoni et al. 2006). X. citri subsp. citri (syn. $X$. axonopodis pv. citri, $X$. campestris pv. citri, or $X$. citri) is the causative agent of citrus bacterial canker disease, which is distributed in many tropical and subtropical citrus growing areas and has a significant impact on citrus markets and trade worldwide (Civerolo 1984; Graham et al. 2004). Citrus-producing areas without citrus canker consider $X$. citri subsp. citri a quarantine pest and subject it to strict international regulation. $X$. citri subsp. citri is spread primarily by rain splash; it enters its hosts through openings such as stomata and wounds and forms distinctive raised, necrotic lesions surrounded by oily, water-

Corresponding author: Nian Wang; E-mail: nianwang@ufl.edu; Telephone: +1.863 .956 .1151 ; Fax: +1.863 .956 .4631 .

* The $\boldsymbol{e}$-Xtra logo stands for "electronic extra" and indicates that two supplementary figures and two supplementary tables are published online. soaked margins and yellow chlorotic rings on leaves, stems, and fruits (Brunings and Gabriel 2003; Stall and Seymour 1983). Eventually, the epidermis ruptures, and massive numbers of pathogen cells emerge to the plant surface, where the bacteria are readily available for rain splash and repeated infection cycles (Duan et al. 1999). Severe invasion by the pathogen leads to defoliation, dieback, and fruit-drop, and the infected fruit is less valuable or completely unmarketable (Gottwald et al. 2002). However, no efficient, environmentally friendly treatment has been developed to control the disease once the pathogen has been established (Graham et al. 2004).

Intensive studies of the molecular virulence mechanism of the citrus canker pathogen have been reported (Brunings and Gabriel 2003; Moreira et al. 2010). PthA, the type III secretion system (T3SS) effector, is a canker pathogenicity determinant and is widely present in the Xanthomonas spp. that causes citrus canker disease (Cubero and Graham 2002; Swarup et al. 1992). The exogenous insertion of the pthA gene confers the ability to elicit canker disease in citrus plants to $X$. axonopodis pv. citrumelo, which causes citrus bacterial spot disease without eliciting the erumpent lesions (Swarup et al. 1991). Transient expression of $p t h A$ in host plant cells was sufficient to induce citrus canker symptoms including hypertrophy, hyperplasia, and cell death (Duan et al. 1999). PthA is transported via the T3SS, which comprises the products of the hrp gene cluster. The transcriptional expression of hrp genes is induced in planta and is regulated by the HrpG and HrpX regulators (Alegria et al. 2004; Guo et al. 2011; Wengelnik and Bonas 1996; Wengelnik et al. 1996), and mutations in the $h r p G$ or $h r p X$ genes in $X$. citri subsp. citri resulted in a loss of pathogenicity in citrus (Guo et al. 2011; Laia et al. 2009). In addition to the pthA and hrp genes, other virulence-related genes are required for $X$. citri subsp. citri to cause disease (Brunings and Gabriel 2003). For example, ops $X$ has been reported to play roles in the production of lipopolysaccharides (LPS) and extracellular polysaccharides (EPS), growth, and virulence in planta (Kingsley et al. 1993). The pgi mutant was unable to grow on minimal medium containing fructose or glycerol as the sole carbon source and was unable to multiply in lemons (Citrus limon) (Tung and Kuo 1999). The diffusible signaling factor (DSF)-mediated rpf quorum-sensing system was reported to positively regulate genes that encode EPS, extracellular enzymes such as proteases, endoglucanases, and other virulence genes in lemons (Siciliano et al. 2006). The gum gene cluster is responsible for the biosynthesis of EPS in many xanthomonads, and a mutant of gumB showed defective EPS production and biofilm formation and led to reduced disease symptoms in lemons (Rigano et al. 2007). A knockout of the galU gene 
caused a reduction in EPS levels, an inability to grow in planta, and no symptoms in grapefruit (Guo et al. 2010). Furthermore, mutations in the LPS biosynthesis genes wxacO and $r f b C$ resulted in deficiency in motility, stress resistance, and virulence in grapefruit (Li and Wang 2011). Additionally, the ColR/ColS two-component regulatory system (TCRS) was reported to play multiple roles in LPS and catalase production, biofilm formation, stress resistance, and transcription of $h r p D 6$ and $h p a F$, and the knockout of either colR or colS resulted in a loss of pathogenicity in grapefruit (Yan and Wang 2011).

Although significant progress has been made in identifying important virulence genes that are involved in canker disease

Table 1. Virulence-related and essential growth-related genes identified in this work and the phenotypes of the mutants in minimal medium and host plants.

\begin{tabular}{|c|c|c|c|c|c|}
\hline Gene ID ${ }^{\mathrm{a}}$ & Gene $^{b}$ & Function of gene product ${ }^{\mathrm{c}}$ & Insertion site $^{\mathrm{d}}$ & Growth in planta ${ }^{e}$ & e Growth on M9 plate \\
\hline \multicolumn{6}{|c|}{ Secretion systems } \\
\hline XAC3534 & xpsD\$++ & General secretion pathway protein D & 4178715 & +++ & ++ \\
\hline XAC3535\# & $x p s N \S+$ & General secretion pathway protein $\mathrm{N}$ & 4181542 & +++ & ++ \\
\hline XAC3536\# & $x p s \$+$ & General secretion pathway protein $\mathrm{M}$ & 4181884 & ++ & ++ \\
\hline XAC3542 & $x p s G \S+$ & General secretion pathway protein $G$ & 4185890 & +++ & ++ \\
\hline XAC3543 & $x p s F \S+$ & General secretion pathway protein $\mathrm{F}$ & 4187142 & ++ & ++ \\
\hline XAC3544 & $x p s E \S+$ & General secretion pathway protein $\mathrm{E}$ & 4188184 & +++ & ++ \\
\hline XAC0396 & hpaB§+ & T3SS HpaB protein & 470195 & ++ & ++ \\
\hline $\mathrm{XAC} 0405$ & $\operatorname{hrcV} \S+$ & T3SS HrcV protein & 477286 & + & ++ \\
\hline XAC0412 & $h r c N \S+$ & T3SS HrcN protein & 481742 & + & ++ \\
\hline \multicolumn{6}{|l|}{ T3SS effector } \\
\hline XACb0065* & pthA4§++ & T3SS effector of AvrBs3/PthA family & 58482 & +++ & ++ \\
\hline \multicolumn{6}{|c|}{ Metabolic pathway } \\
\hline $\mathrm{XAC} 0033$ & glt $B$ & Glutamate synthase alpha subunit & 41666 & +++ & - \\
\hline XAC0476 & $\operatorname{trp} E \S+$ & Anthranilate synthase component I & 567293 & +++ & - \\
\hline $\mathrm{XAC} 0478^{*}$ & $\operatorname{trpG} \S+$ & Anthranilate synthase component II & 569312 & ++++ & + \\
\hline$\underline{\mathrm{XAC} 0481} *$ & $\operatorname{trpC}$ & Indole-3-glycerol phosphate synthase & 571902 & +++ & - \\
\hline$\underline{\mathrm{XAC} 2717}$ & $\operatorname{trp} B \S$ & Tryptophan synthase beta chain & 3177648 & +++ & - \\
\hline$\overline{\mathrm{XAC} 2496}$ & NA & Glutamate dehydrogenase & 2912244 & ++++ & ++ \\
\hline$\underline{\mathrm{XAC} 2725}$ & $\operatorname{aroc} \S$ & Chorismate synthase & 3186589 & + & - \\
\hline$\overline{\mathrm{XAC} 3010} \#$ & $\operatorname{aroK} \S+$ & Shikimate kinase & 3520694 & ++++ & - \\
\hline$\underline{\mathrm{XAC} 3458}$ & $l e u C \S+$ & 3 -isopropylmalate dehydratase large subunit & 4080401 & ++++ & + \\
\hline$\overline{\mathrm{XAC} 3494}$ & $\operatorname{aspC}$ & Aspartate aminotransferase & 4132553 & ++ & ++ \\
\hline$\underline{\mathrm{XAC} 1835}$ & hisI§+ & Phosphoribosyl-AMP cyclohydrolase & 2130611 & ++++ & + \\
\hline XAC1808 & NA & Aldehyde dehydrogenase & 2081819 & ++++ & ++ \\
\hline XAC1139 & $\operatorname{acn} A$ & Aconitate hydratase 1 & 1291310 & ++++ & + \\
\hline XАC1788 & pgi§++ & Glucose-6-phosphate isomerase & 2057186 & + & ++ \\
\hline XAC1840 & $\mathrm{NA}$ & Sugar aldolase & 2135693 & +++ & ++ \\
\hline XАC3890 & putA & Bifunctional PutA protein & 4574489 & NSD & ++ \\
\hline XAC1247\# & uvrA & Excinuclease $\mathrm{ABC}$ subunit $\mathrm{A}$ & 1425150 & ++ & ++ \\
\hline$\underline{\mathrm{XAC} 0511^{*}}$ & purD & Phosphoribosylamine-glycine ligase & 600972 & +++ & - \\
\hline$\underline{\mathrm{XAC} 0513}$ & purH§+ & Bifunctional purine biosynthesis protein & 603947 & ++++ & - \\
\hline$\underline{\mathrm{XAC} 1032}$ & purF§ & Amidophosphoribosyltransferase & 1190150 & + & - \\
\hline$\underline{\underline{\mathrm{XAC}} 3549}$ & purL & $\begin{array}{l}\text { Phosphoribosylformylglycinamidine } \\
\text { synthetase }\end{array}$ & 4207480 & +++ & - \\
\hline$\underline{\mathrm{XAC} 0012}$ & $p d x J \S+$ & Pyridoxal phosphate biosynthetic protein & 13736 & ++++ & - \\
\hline$\underline{\mathrm{XAC} 3068}$ & bioA§ & $\begin{array}{l}\text { Adenosylmethionine- } 8 \text {-amino- } 7 \text { - } \\
\text { oxononanoate aminotransferase }\end{array}$ & 3589299 & NSD & + \\
\hline XAC0387 & bioF§ & 8-amino-7-oxononanoate synthase & 458172 & +++ & - \\
\hline$\overline{\mathrm{XAC} 1099}$ & moaD & Molybdopterin-converting factor chain 1 & 1251717 & NSD & ++ \\
\hline$\underline{\mathrm{XAC} 2778}$ & $n a d D$ & Nicotinate-nucleotide adenylyltransferase & 3257107 & ++ & - \\
\hline$\underline{\mathrm{XAC} 3220}$ & nadE§ & NH3-dependent NAD synthetase & 3793982 & ++ & - \\
\hline XAC0618* & hrpM§++ & Periplasmic glucan biosynthesis protein & 733719 & ++ & ++ \\
\hline XAC0014 & cls $\S++$ & Cardiolipin synthetase & 15609 & NSD & ++ \\
\hline XAC2292\# & galU§++ & $\begin{array}{l}\text { UTP-glucose-1-phosphate } \\
\text { uridylyltransferase }\end{array}$ & 2682811 & +++ & ++ \\
\hline XAC3602 & $m e t B \S+$ & Cystathionine gamma-lyase-like protein & 4273998 & ++++ & ++ \\
\hline \multicolumn{6}{|c|}{ EPS and LPS production } \\
\hline XAC2576 & gumK§+ & GumK protein & 3035219 & +++ & ++ \\
\hline XAC2581\# & gumF§+ & GumF protein & 3041792 & +++ & 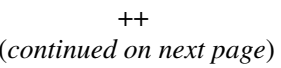 \\
\hline
\end{tabular}

a \#: Transposon insertion may have a polar effect. *: Mutants that have been complemented to the virulence in planta by a corresponding gene cloned from wild type. Essential physiological genes are underlined. The mutants inserted by EZ-Tn5 in the intergenic region are also listed.

${ }^{b}$ NA: not available. $\S$ : Genes that have been reported previously to be virulence-related in the pathogenic bacteria; $\S+$ : Genes that have been reported to be virulence-related in members of genus Xanthomonas; §++: Genes that have been reported to be virulence-related in Xanthomonas citri subsp. citri. Genes common with the Laia and associates (2009) appear in bold font.

${ }^{\mathrm{c}}$ Function of the putative corresponding protein or the putative domain of the hypothetical protein.

${ }^{\mathrm{d}}$ The insertion site of EZ-Tn5 in the chromosome or plasmid of pXAC64 and pXAC33 of strain X. citri subsp. citri 306. The insertion site in one representative mutant was shown here if the same gene was inserted by EZ-Tn5 in more than one mutant.

${ }^{\mathrm{e}}$ Mutants and wild-type were inoculated into the intercellular spaces of citrus leaves at a cell concentration of $10^{6} \mathrm{CFU} / \mathrm{ml}$. The leaves were sampled at 4 days postinoculation, and the bacterial cell density was determined by serial dilution on nutrient agar plates containing corresponding antibiotics. Symbols indicates the value calculated by (cell density of wild-type)/(cell density of mutant): $+=\geq 1,000 ;++=\geq 100$ and $<1,000 ;+++=\geq 10$ and $<100 ;++++=<10$ and significantly lower than wild type. NSD $=$ no significant difference between wild-type and mutant. Significant difference: $P<0.05$, analyzed by Student's two-sample $t$ test.

${ }^{\mathrm{f}}$ Growth of mutants on M9 minimal media plates. $++=$ grow properly similar with wild-type $++=$ grow poorly; $-=$ not grown. 
development, the comprehensive understanding of the virulence mechanism of $X$. citri subsp. citri is lacking and remains to be elucidated. A large number of virulence-related genes were identified by sequencing the genomes of respective pathogens (da Silva et al. 2002; Moreira et al. 2010) as well as transcriptome analyses of critical virulence regulatory genes, such as $h r p X$ and $h r p G$ (Guo et al. 2011). However, their roles in virulence have not been experimentally determined. Tn5-mediated mutagenesis screening is an efficient method for creating mutants and has been used for high-throughput screening of potential virulence-related genes in several Xanthomonas members (Laia et al. 2009; Qian et al. 2005; Rott et al. 2011; J. Wang et al. 2008). The genome of X. citri subsp. citri 306 has been sequenced and is a good model system for investigating

Table 1. (continued from previous page)

\begin{tabular}{|c|c|c|c|c|c|}
\hline Gene ID ${ }^{a}$ & Gene $^{b}$ & Function of gene product ${ }^{c}$ & Insertion site ${ }^{d}$ & Growth in planta ${ }^{\mathrm{e}}$ & Growth on M9 plate f $^{f}$ \\
\hline \multicolumn{6}{|c|}{ EPS and LPS production (continued) } \\
\hline XAC3598 & $r f b C \S++$ & Truncated O-antigen biosynthesis protein & 4268484 & ++++ & ++ \\
\hline XAC3599 & NA & Hypothetical protein & 4270078 & +++ & ++ \\
\hline XAC3600 & $w z t \S++$ & ABC transporter ATP-binding protein & 4271693 & +++ & ++ \\
\hline XAC3601 & $w z m \S+$ & $\mathrm{ABC}$ transporter permease & 4273662 & ++++ & ++ \\
\hline \multicolumn{6}{|l|}{ Regulatory element } \\
\hline XAC $1548 *$ & NA & Transcriptional regulator GntR family & 1789466 & + & ++ \\
\hline XAC 1878 & $\operatorname{rpfC} \S++$ & RpfC protein & 2180203 & NSD & ++ \\
\hline XAC2358 & $d k s A \S$ & Regulator of rRNA expression & 2753209 & ++ & ++ \\
\hline XAC2670 & NA & TCRC LytT family, sensor histidine kinase. & 3128487 & ++ & ++ \\
\hline \multicolumn{6}{|l|}{ Transport protein } \\
\hline $\mathrm{XAC} 0010$ & $\operatorname{exbD1\S +}$ & Biopolymer transport ExbD1 protein & 12925 & + & ++ \\
\hline XAC0642\# & $r m r B$ & MFS transporter & 756373 & NSD & ++ \\
\hline XAC2293 & NA & Epimerase & 2684644 & +++ & ++ \\
\hline XAC2334 & cydC§ & $\mathrm{ABC}$ transporter ATP-binding protein & 2728289 & NSD & ++ \\
\hline$\underline{\mathrm{XAC} 2468}$ & $\operatorname{corA} \S+$ & Magnesium and cobalt transport protein & 2872360 & ++++ & + \\
\hline$\overline{\mathrm{XAC} 4217}$ & $t a t B \S$ & Sec-independent protein translocase & 4976723 & NSD & ++ \\
\hline XAC4216 & tat $C \S+$ & Sec-independent protein translocase & 4976057 & ++ & ++ \\
\hline XAC4340 & $y r b E \S$ & Toluene tolerance protein & 5135801 & NSD & ++ \\
\hline \multicolumn{6}{|l|}{ Protein fate } \\
\hline XAC0019 & ompP1§ & Outer membrane protease & 20681 & ++++ & ++ \\
\hline XAC1585 & NA§+ & Peptidyl-prolyl cis-trans isomerase & 1831534 & ++ & ++ \\
\hline XAC2001 & $\operatorname{clp} A \S+$ & ATP-dependent Clp protease subunit & 2337204 & ++++ & ++ \\
\hline \multicolumn{6}{|c|}{ Plasmid mobilization and stabilization } \\
\hline XAC1507 & $m o b L \S$ & Plasmid mobilization protein & 1739717 & +++ & ++ \\
\hline $\mathrm{XACa0028}$ & pemI & Plasmid stable inheritance protein I & 18713 & ++ & ++ \\
\hline \multicolumn{6}{|l|}{ Extracellular enzyme } \\
\hline $\mathrm{XAC} 0661 *$ & peh-1§++ & Endopolygalacturonase & 784188 & NSD & ++ \\
\hline \multicolumn{6}{|l|}{ Adhesion } \\
\hline XAC1812\# & $h m s F$ & Polysaccharide deacetylase & 2085866 & ++++ & ++ \\
\hline \multicolumn{6}{|l|}{ Hypothetical gene } \\
\hline XAC0007\# & NA & $\begin{array}{l}\text { Tetratrico peptide repeat (TPR); signal } \\
\text { peptide }\end{array}$ & 10317 & +++ & ++ \\
\hline XAC0013 & NA & Signal peptide & 14688 & +++ & ++ \\
\hline XAC0464 & NA & No known domain & 554061 & NSD & ++ \\
\hline$\underline{\mathrm{XAC} 1142}$ & NA & PRPF domain & 1293608 & ++++ & - \\
\hline$\underline{\mathrm{XAC} 1230} *$ & NA & Polyketide cyclase; Signal peptide & 1408918 & ++ & - \\
\hline$\overline{\mathrm{XAC} 1347}$ & NA & Signal peptide & 1554134 & NSD & ++ \\
\hline XAC1434 & NA & $\begin{array}{l}\text { Domain present in carbohydrate binding } \\
\text { proteins and sugar hydrolyses (CASH) }\end{array}$ & 1654334 & + & ++ \\
\hline XAC1496 & NA & Signal peptide & 1728074 & + & ++ \\
\hline XAC2307 & NA & F5/8 type C domain; Signal peptide & 2697403 & NSD & ++ \\
\hline XAC2357\# & NA & Five transmembrane domains & 2753636 & ++ & + \\
\hline$\overline{\mathrm{XAC} 2673}$ & NA & No known domain & 3134049 & ++++ & ++ \\
\hline XAC2903 & NA & Phage integrase domain & 3409390 & +++ & ++ \\
\hline XAC2976 & NA & P-loop ATPase protein family & 3477864 & ++++ & ++ \\
\hline XАC $3049 *$ & NA & Signal peptide & 3567127 & + & ++ \\
\hline XAC3576 & NA & Transmembrane domain & 4242586 & NSD & ++ \\
\hline XAC3795 & NA & Glyphos-transf domain & 4464472 & ++ & ++ \\
\hline \multicolumn{6}{|l|}{ Intergenic region } \\
\hline XAC0007-0008 & XAC0007-tonB & 10913 & +++ & ++ & \\
\hline XAC0008-0009 & ton $B-e x b B$ & 11731 & + & - & \\
\hline XAC0122-0123 & tldD-XAC0123 & 144933 & +++ & ++ & \\
\hline XAC0333-0334 & $m e t R-s f l A$ & 399501 & ++++ & + & \\
\hline XAC1521-1522 & grpE-dnaK & 1755217 & + & + & \\
\hline XAC1988-1989 & flgA-flgM & 2321007 & NSD & ++ & \\
\hline XAC1990-1991 & XAC1990-1991 & 2321849 & ++++ & ++ & \\
\hline XAC2576-2577 & gumK-gumJ & 3036089 & +++ & ++ & \\
\hline XAC3273-3274 & XAC3273-cheY & 3855976 & ++++ & - & \\
\hline XAC3575-3576 & Etf-QO-XAC3576 & 4240787 & +++ & ++ & \\
\hline XAC3578-3579 & ipsI-xanA & 4244075 & NSD & ++ & \\
\hline XAC3597-3598 & XAC3597-rfbC & 4267725 & +++ & ++ & \\
\hline XAC3599-3600 & XAC3599-wzt & 4270688 & +++ & ++ & \\
\hline XACb0012-0013 & XACb0012-0013 & 12393 & ++++ & ++ & \\
\hline
\end{tabular}


pathogen-host interactions (Brunings and Gabriel 2003; da Silva et al. 2002). A mutant library of strain 306 was constructed previously in our group (Guo et al. 2010). In the present study, approximately 22,000 mutants were individually screened for virulence deficiency in grapefruit (Citrus paradise Macf. cv. Duncan). In total, 59 putative virulence-related genes, including 27 novel genes, were identified to be involved in citrus canker symptom development, thereby significantly advancing our understanding of the genetic basis underlying the virulence mechanism of citrus canker pathogen.

\section{RESULTS}

\section{High-throughput screening} of virulence-deficient mutants of $X$. citri subsp. citri.

A mutant library of $X$. citri subsp. citri 306 was previously constructed using the EZ-Tn5 mutagenesis kit (Guo et al. 2011). To understand the genetic basis of the pathogen's virulence mechanism, a total of 22,000 mutants were individually subjected to a two-time pathogenicity screening protocol using susceptible grapefruit (C. paradise Macf. cv. Duncan). At each screening, the mutants were inoculated into the intercellular spaces of the citrus leaves with two different cell suspensions $\left(10^{6}\right.$ or $\left.10^{8} \mathrm{CFU} / \mathrm{ml}\right)$. Four independent replicates were performed for each mutant at each bacterial concentration, and the experiment was repeated three times. Thus, the pathogenicity assay was performed with at least 24 independent replicates for each mutant. A total of 217 mutants that elicited either no symptoms or reduced symptoms in grapefruit leaves were collected and were subjected to a Southern blot assay to determine the copy number of EZ-Tn5 (Supplementary Fig. S1).
Only one of the mutants was shown to contain two copies of EZ-Tn5 and was excluded from further investigation. The 216 virulence-deficient mutants (containing one single copy of the transposon) were investigated further.

To determine the insertion site of the transposon, the 216 mutants were subjected to a rescue cloning procedure to clone the EZ-Tn5 flanking sequences. The 216 mutants included mutations in 97 protein-coding sequences and intergenic regions, as shown by sequencing and blast analyses of the flanking fragments. In addition to 14 intergenic regions, one gene ( $r p l J)$ encoding a ribosomal protein and 82 genes that were involved in citrus canker symptom development caused by $X$. citri subsp. citri were indentified in this work. Only these 82 genes (excluding the intergenic regions and ribosomal encoding gene) were further investigated in this study (Table 1; Supplementary Table S1). Among the 82 genes, 80 were mapped to the chromosome, and each of the other two was mapped to megaplasmids pXAC64 and pXAC33 of X. citri subsp. citri 306 (Fig. 1). Based on the analysis of protein function, the 82 genes were classified into 11 diverse categories (Table 1). Among the identified genes, 32 genes were previously characterized virulence factors, including 22 genes in the genus Xanthomonas and nine genes in $X$. citri subsp. citri (Table 1). In addition to the 32 previously characterized virulence factors in the pathogenic bacteria, 27 novel genes, including 13 hypothetical genes, were identified in this study as being potentially involved in the pathogenicity of $X$. citri subsp. citri.

To test whether EZ-Tn5 insertion has a polar effect on downstream genes in operons, a polarity analysis was performed for the mutated genes in a putative operon. As listed in Table 1, the insertion of EZ-Tn5 into 10 genes ( $x p s N, \operatorname{xps} M, \operatorname{aroK}, u v r A$,

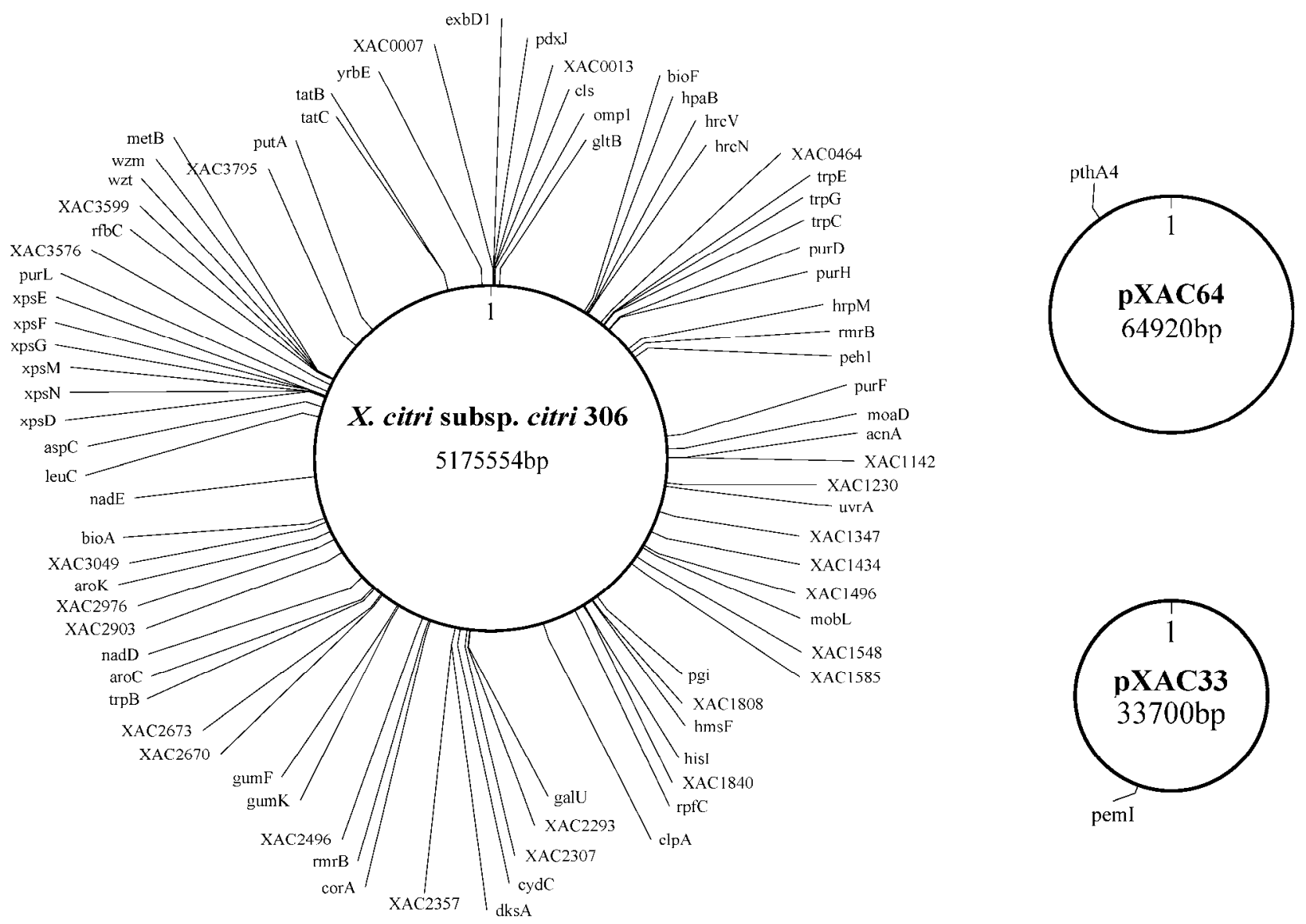

Fig. 1. Distribution of the 82 genes identified in this work. Distribution of the 82 identified genes on the chromosome and two megaplasmids of Xanthomonas citri subsp. citri 306 . The gene name or ID is indicated. 
galU, gumF, rmrB, hmsF, XAC0007, and XAC2357) may have a polar effect on downstream genes within the same operon. For example, both $x p s N$ and $x p s M$ are located in the $x p s$ operon, and the insertion of EZ-Tn5 in either $x p s N$ or $x p s M$ may have a potential polar effect on the downstream gene $x p s D$, which encodes the channel-forming protein in type II secretion system (T2SS) machinery. Moreover, gumF is located in the gum operon, and the insertion of EZ-Tn5 in gumF may have a polar effect on the downstream gum genes that are involved in EPS biosynthesis. Those genes were included for further analysis, since one operon usually contains functionally related genes.

\section{The mutant phenotypes in planta and in vitro.}

Compared with the typical canker disease symptoms caused by the wild-type strain, diverse symptoms were observed in grapefruit leaves following inoculation of the identified virulence-deficient mutants (Table 2). Similar canker symptoms could be induced by inoculating the wild-type strain at concentrations of either $10^{6}$ or $10^{8} \mathrm{CFU} / \mathrm{ml}$. The disease progression with an inoculation of $10^{6} \mathrm{CFU} / \mathrm{ml}$ was delayed by approximately 7 days as compared with the higher inoculation concentration of $10^{8} \mathrm{CFU} / \mathrm{ml}$ (data not shown). In the following analysis, the symptoms were categorized on the basis of the symptoms that were caused by the mutants that were inocu- lated at a concentration of $10^{6} \mathrm{CFU} / \mathrm{ml}$. The symptoms were observed at 4 to 30 days postinoculation (dpi). As summarized in Table 2, the diverse symptoms were classified into five categories. Category I contained mutants that caused no visible symptoms on the grapefruit leaves. Mutated genes in this category included three T3SS genes ( $h p a B, h r c V$, and $h r c N$ ), four genes of the metabolism pathways ( $p g i$, nadD, hrpM, and galU), two genes encoding regulators ( $d k s A$ and XAC1548), one gene encoding a transporter (exbD1), and two hypothetical genes (XAC1230 and XAC3049). Category II mutants caused clearly evident chlorosis but no visible canker lesions on the grapefruit leaves. Mutated genes in this category included the T3SS effector gene pthA4 and the hypothetical gene XAC1496. Category III mutants caused a reduction in water soaking and caused thicker lesions than the wild-type strain. Mutated genes in this category contained gumK and gumF of the EPS biosynthesis cluster. Category IV mutants caused delayed canker lesion symptoms on the grapefruit leaves. The mutants caused water-soaking and lesion symptoms on citrus leaves, but the development of these symptoms was markedly delayed compared with simultaneously inoculated wild-type strain. Mutated genes in this category included six genes in the T2SS (xpsD, xpsM, xps $N, x p s E, x p s F$, and $x p s G$ ), five genes of metabolism pathways ( $g l t B, \operatorname{trp} G, \operatorname{trp} C$, leuC, and XAC1840), two genes encoding transporters (tat $B$ and $t a t C)$, one gene of

Table 2. Classification of identified genes based on the symptoms in host plants caused by respective mutants

\begin{tabular}{|c|c|c|}
\hline Category $^{\mathrm{a}}$ & Representative symptoms ${ }^{b}$ & Mutated genes \\
\hline I, No symptoms & & $\begin{array}{l}\text { hpaB, hrcV, hrcN, pgi, nadD, hrpM, galU, dksA, exbD1, XAC1230, XAC1548, } \\
\text { XAC3049 }\end{array}$ \\
\hline II, Chlorosis only & & pthA4, XAC1496 \\
\hline $\begin{array}{l}\text { III, Reduced water soaking } \\
\text { and thicker lesion }\end{array}$ & & gumK, gumF \\
\hline IV, Delayed symptoms & & $\begin{array}{l}x p s D, x p s N, x p s M, x p s G, x p s F, x p s E, \text { gltB, } \operatorname{trp} G, \operatorname{trpC}, \text { leuC, tatB, tatC, clpA, peh- } \\
\text { 1, XAC1142, XAC1840 }\end{array}$ \\
\hline V, Fewer symptoms & & $\begin{array}{l}\text { aroC, aroK, trpE, trpB, aspC, hisI, acnA, putA, uvrA, purD, purH, purF, purL, } \\
\text { pdxJ, bioA, bioF, moaD, nadE, cls, wzt, wzm, metB, rfbC, rpfC, ompP1, rmrB, } \\
\text { cydC, corA, yrbE, mobL, pemI, hmsF, XAC0007, XAC0013, XAC0464, } \\
\text { XAC1347, XAC1434, XAC1585, XAC1808, XAC2293, XAC2307, XAC2357, } \\
\text { XAC2496, XAC2670, XAC2673, XAC2903, XAC2976, XAC3576, XАC3599, } \\
\text { XAC3795 }\end{array}$ \\
\hline
\end{tabular}

\footnotetext{
${ }^{a}$ Mutants and wild type were inoculated into the intercellular spaces of citrus leaves at a cell concentration of $10^{6} \mathrm{CFU} / \mathrm{ml}$. Symptoms were observed from 4 to 30 days postinoculation and symptoms caused by different mutants were classified into five categories.

${ }^{\mathrm{b}}$ Only the symptom caused by one representative mutant was present in each category. $\mathrm{W}=$ wild-type; $\mathrm{M}=$ mutant. The representative mutants used in each category were as follows: category I, the mutant of $h r c V$; II, the mutant of pthA4; III, the mutant of gumK; IV, the mutant of $x p s D$; and V, the mutant of aroK.
} 
protein fate $(\operatorname{clp} A)$, one gene encoding an extracellular enzyme (peh-1), and one hypothetical gene (XAC1142). Category V mutants caused citrus canker lesions, but these symptoms were much milder than those of the wild-type strain. Mutated genes in this category contained 22 genes of metabolism pathways (aroC, aroK, trpE, trpB, aspC, hisI, acnA, putA, uvrA, purD, purH, purF, purL, pdxJ, bioA, bioF, moaD, nadE, cls, metB, XAC1808, and XAC2496), four genes in the LPS biosynthesis gene cluster ( $w z t, w z m, r f b C$, and XAC3599), two genes encoding regulators ( $r p f C$ and XAC2670), five genes encoding transporters ( $r m r B, c y d C, \operatorname{corA}, y r b E$, and XAC2293), two genes of protein fate (ompPl and XAC1585), two genes of plasmid stabilization and mobilization ( $m o b L$ and pemI), one gene of adhesion $(\mathrm{hmsF}$ ), and 12 hypothetical genes (XAC0007, XAC0013, XAC0464, XAC1347, XAC1434, XAC2307, XAC2357, XAC2673, XAC2903, XAC2976, XAC3576, and XAC3795).

To understand how various genes contribute to virulence, growth of the mutants in planta was investigated. Each of the mutants was inoculated into the intercellular space of grapefruit leaves, using a $10^{6} \mathrm{CFU} / \mathrm{ml}$ cell suspension. The inoculated leaves were sampled at 0,2 , and $4 \mathrm{dpi}$, and the bacterial cell density was measured using serial dilutions on nutrient agar (NA) plates. No significant difference in bacterial density was observed at $0 \mathrm{dpi}$, ensuring that any differences among the strains at later stages would not be due to different initial concentrations. Only the results at $4 \mathrm{dpi}$ are presented here. As shown in Table 1, compared with the wild-type strain, mutations in nine genes caused more than a 1,000-fold reduction in cell density inside the grapefruit leaves; mutations in 17 genes caused 100- to 1,000-fold reductions of cell density inside the leaves; mutations in 23 genes caused 10- to 100-fold reductions of cell density inside the leaves; mutations in 19 genes caused less than 10 -fold reductions.

In addition to the phenotypes that were observed in planta, the phenotypes of these mutants were also assayed in vitro by measuring growth on minimal medium plates and observing colony morphology on NA plates. Mutants of nine genes (galU, gumK, gumF, rfbC, wzt, wzm, metB, rpfC, and XAC2293) formed nonmucoid colonies on the NA plates, and mutants of six genes ( $g l t B, \operatorname{trp} E$, aroC, aroK, XAC2357, and $\mathrm{XAC} 1142$ ) formed white colonies on the NA plates. Additionally, mutants of 16 genes showed no growth and mutants of seven genes grew poorly on M9 minimal medium plates (Table 1 ), indicating that these 23 genes are required for the proper bacterial growth in vitro. Thus, these 23 genes were classified as essential genes and the other 59 genes were classified as putative virulence-related genes in this work (Table 1).

\section{General metabolism factors.}

The category of the general metabolism pathway contains the largest number of genes (31 in total) identified in this study (Table 1). As shown in Figure 2, 26 of these genes were sorted into 12 different pathways on the basis of their analysis, using the Kyoto Encyclopedia of Genes and Genomes (KEGG) database. These 12 pathways are involved in the metabolism of many essential compounds and include vitamin B6 metabolism; glycolysis and gluconeogenesis; the citrate cycle; alanine, aspartate, and glutamate metabolism; nicotinate and nicotinamide metabolism; phenylalanine, tyrosine, and tryptophan biosynthesis; glycerophospholipid metabolism; biotin metabolism; histidine metabolism; purine metabolism; cysteine and methionine metabolism; and valine, leucine, and isoleucine metabolism. Of the 31 metabolism-related genes, 19 were classified as essential genes, since the individual mutation of these 19 genes led to auxotrophic or poor growth in minimal medium and the other 12 genes were classified as putative virulence-related genes (Table
1; Fig. 2). Knockout of four genes (pgi, nadD, hrpM, and galU) caused no symptoms (symptom category I) on grapefruit leaves. Knockout of five genes $(\mathrm{gltB}, \operatorname{trp} G, \operatorname{trp} C, \operatorname{leu} C$, and XAC1840) caused delayed symptoms (symptom category IV) on grapefruit leaves. Mutants of the other 21 genes caused milder symptoms (symptom category V) on grapefruit leaves. The cell densities of the mutants were significantly lower than those of the wild-type strain in planta, with the exceptions of mutants in putA, bioA, $m o a D$, and $c l s$, which were not significantly different from wild type at 4 dpi. The virulence of four mutants $(\operatorname{trp} G, \operatorname{trp} C, \operatorname{purD}$, and $h r p M$ ) was restored to the wild-type level by complementation using the intact corresponding genes (Table 1).

\section{Mutants in T2SS caused delayed symptom development in host plants.}

In a wide variety of pathogenic bacteria, T2SS mediates the transportation of toxins and hydrolytic enzymes from the periplasmic space, across the outer membrane to the extracellular surroundings (Pugsley 1993). In our screening, six T2SS-related genes ( $x p s D, x p s M, x p s N, x p s E, x p s F$, and $x p s G$ ) were identified to potentially contribute to the virulence of the canker pathogen (Table 1; Fig. 3). Mutations in these six xps genes caused delayed symptoms (symptom category IV) in host plants. Compared with wild-type, all six xps mutants showed fewer symptoms at $8 \mathrm{dpi}$ and caused more water soaking in the citrus leaves at 15 dpi. In addition, the canker lesion symptom was observed with the mutants but appeared approximately one week later than with wild type (Fig. 3D). The cell densities of the xps mutants in the intercellular space of the leaves were reduced compared with wild type (Table 1). A variety of degrading enzymes are secreted via the T2SS in Xanthomonas spp., including protease, amylase, pectate lyase, cellulase, and xylanase (Baptista et al. 2010; Furutani et al. 2004; Lee et al. 2004; Szczesny et al. 2010). Consistently, the extracellular activities of protease and amylase of all six xps mutants were much lower than those of the wild-type strain (Fig. 3B and C).

\section{T3SS and $p t h A 4$ are essential}

\section{for the virulence of $X$. citri subsp. citri.}

T3SS plays important roles in the hypersensitive response and pathogenicity of gram-negative bacterial pathogens. Three genes of the T3SS ( $h p a B, h r c V$, and $h r c N$ ) were identified in our screening (Table 1). All three mutants caused no visible symptoms (symptom category I) on grapefruit leaves, and the cell densities of the mutants were significantly reduced in planta, which was more than 100 -fold lower than that of the wild type. One T3SS effector gene, pthA4 (XACb0065), was also identified in this work. Surprisingly, 50 separate mutants were identified in the pthA4 gene (Fig. 4A), which accounts for $23.1 \%$ of all identified virulence-deficient mutants, and all of these pthA4 mutants caused similar phenotypes in planta (data not shown). Following inoculation, the pthA4 mutants caused only chlorosis on the citrus leaves (symptom category II) (Fig. 4B). Although the pthA4 mutant proliferated in the intercellular spaces of the grapefruit leaves, the cell density of the pthA mutant was 20-fold lower than that of the wild type at 4 dpi (Table 2; Fig. 4C). To confirm the role of pthA4 in pathogenicity, the intact wild-type pthA4 gene was cloned and was transformed into five randomly chosen pthA4 mutants. All of the complemented strains regained the ability to cause citrus canker symptoms and proliferate in the intercellular spaces of citrus leaves at levels that were similar to the wild-type strain (Fig. 4B and C).

\section{Plasmid mobilization and stabilization factors.}

The mobL and pemI genes, which encode putative proteins for plasmid mobilization and stabilization, were identified in 
this work (Table 1). The mobL (XAC1507) gene encodes a putative plasmid conjugative transfer protein that belongs to the MobL/MobA family. Mutants of mobL developed fewer symptoms (symptom category $\mathrm{V}$ ) in citrus leaves, and the bacterial density inside the leaves was 38-fold lower than that of the wild-type strain at $4 \mathrm{dpi}$. The other gene, pemI, is located on megaplasmid pXAC33. Interestingly, gene pemI (XACa0028) and downstream gene pemK (XACa0027) potentially comprise a toxin-antitoxin (TA) system in $X$. citri subsp. citri (da Silva et al. 2002). Generally, a TA system consists of a stable toxin and an unstable antitoxin that interferes with the toxin's lethal action (Hayes 2003). In the present study, a mutation of the putative antitoxin coding gene pemI caused a dramatic reduction in cell density (212-fold lower than that of wild type) and virulence in host plants (symptom category V) (Table 2). The mobL and pemI genes were classified into the virulence-related genes category rather than the essential genes category because mutants of the respective genes still grew in vitro and in planta (Table $1)$.

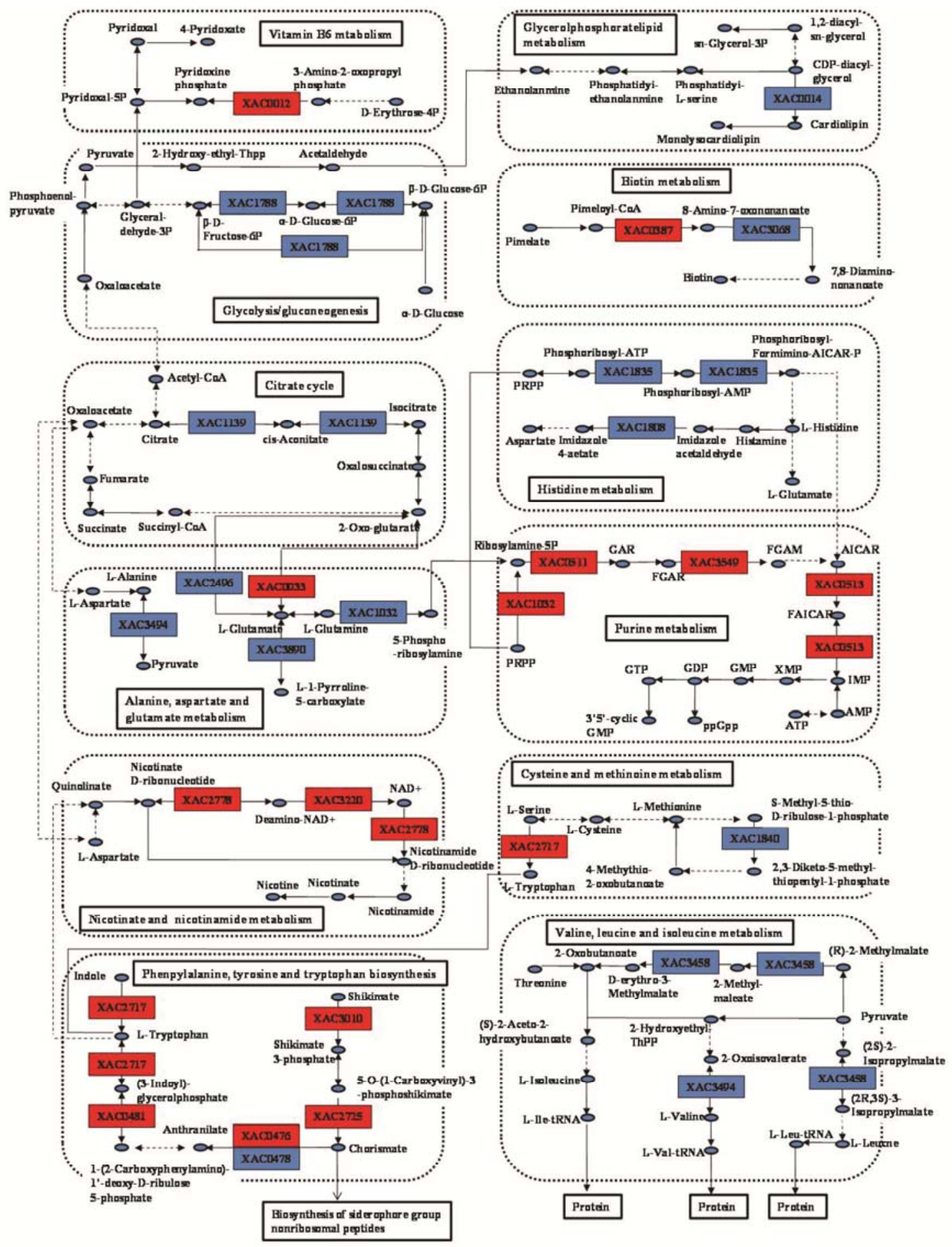

Fig. 2. Schematic metabolism pathways of genes involved in general metabolism. In this work, 26 genes were identified and were sorted into 12 metabolism pathways according to Kyoto Encyclopedia of Genes and Genomes (KEGG) analysis. Different pathways are defined using black rectangle. Genes shown in red indicate that mutants of the respective genes are auxotrophic on M9 minimal medium plate. Arrows represent the direction of the pathway. Arrow lines with dashes mean multiple steps were involved in the reactions. Lines without arrowheads mean the same compound in different pathways. 


\section{Regulatory factors.}

Although a large number of regulatory genes have been uncovered by whole-genome sequencing, only a few have been investigated for their roles in the virulence mechanism of Xanthomonas species (Büttner and Bonas 2010; Qian et al. 2008). In the present study, four regulatory genes were found to potentially contribute to the virulence of $X$. citri subsp. citri (Table 1). In addition to the previously reported quorum-sensing sensor kinase gene $\operatorname{rpfC}$ (Siciliano et al. 2006), we found that a mutation of $d k s A$, which encodes an expression regulator of ribosomal RNA, abolished pathogenicity in grapefruit. DksA has been reported to play a role in regulating the virulence of Escherichia coli (Paul et al. 2004), Salmonella typhimurium (Webb et al. 1999), Shigella flexneri (Mogull et al. 2001), and Pseudomonas aeruginosa (Jude et al. 2003). However, the biological role of DksA has not been characterized in Xanthomonas spp. Additionally, the XAC 1548 gene encodes a putative GntR family regulator that was named after the Bacillus subtilis repressor of the gluconate operon (Haydon and Guest 1991). Mutation in XAC1548 resulted in a loss of pathogenicity in the host plant (symptom category I) (Table 2; Fig. 5A). A growth assay revealed that the bacterial population of the mutant of XAC 1548 was significantly lower than that of the wild type inside the intercellular spaces of host leaves (Fig. 5B). For complementation, the gene of XAC1548 was cloned from the wild type and was transformed into the mutant. As we ex- pected, the complementary strain caused similar symptoms to those of the wild type and the bacterial population was also restored to the wild-type level in the host plant (Fig. 5). Furthermore, XAC2670 encodes a putative histidine kinase sensor of the TCRS and has a high similarity ( $81 \%$ in amino acid sequence) to $\mathrm{AlgZ}$ (also called FimS) in $P$. aeruginosa. The sensor AlgZ, possibly by interacting with the cognate regulator AlgR, has been shown to be a repressor of alginate biosynthesis (Yu et al. 1997) and an activator of type IV pili-mediated twitching motility (Whitchurch et al. 1996, 2002) in P. aeruginosa. Mutations in XAC2670 caused a notable deficiency of virulence (symptom category $\mathrm{V}$ ) and a significant reduction of growth in host plants (Tables 1 and 2).

\section{EPS and LPS biosynthesis genes.}

EPS has long been recognized as an important virulence factor for many pathogenic bacteria (Leigh and Coplin 1992). Interestingly, recent reports revealed that the gum genes of $X$. citri subsp. citri are required for virulence in C. limon (Rigano et al. 2007) but are dispensable for bacterial growth and disease formation in $C$. sinensis (Dunger et al. 2007), suggesting that the contribution of EPS to virulence may depend on the host plant and environmental conditions (Büttner and Bonas 2010). In our screening, two gum genes (gumF and gumK) were identified as being involved in the virulence of $X$. citri subsp. citri in grapefruit (C. paradise Macf. cv. Duncan). Both

A

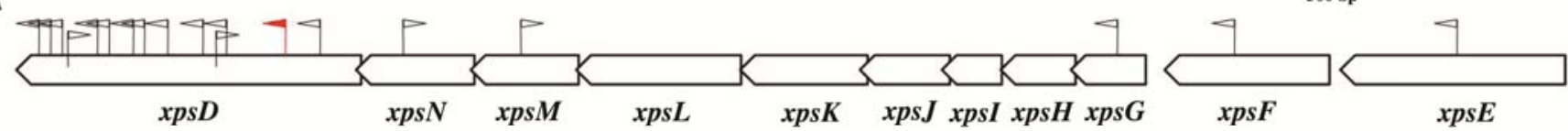

B

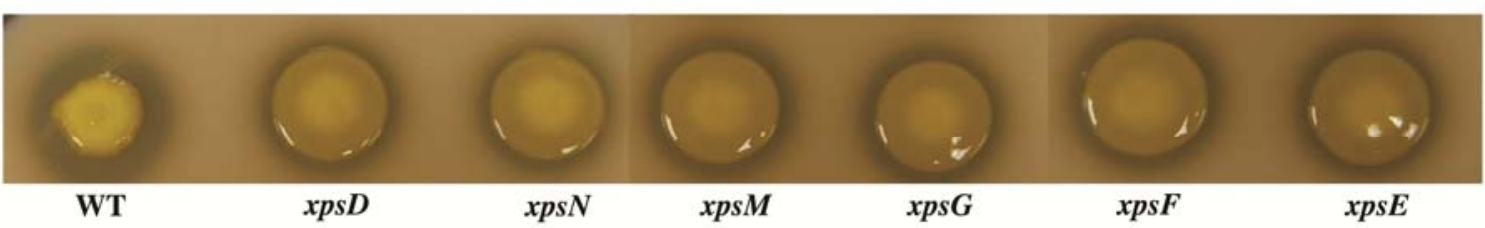

C

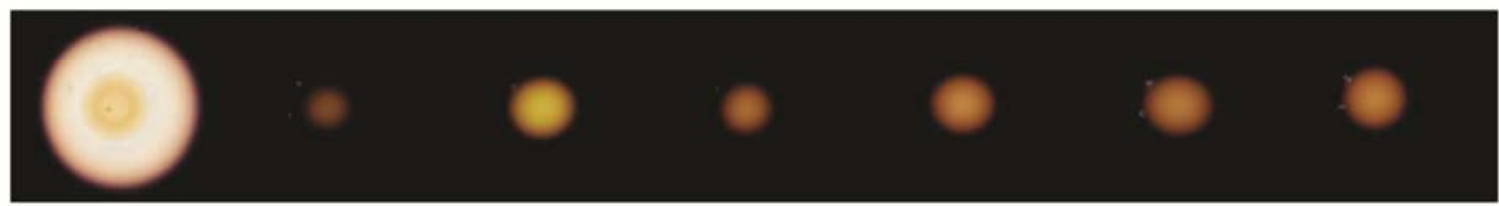

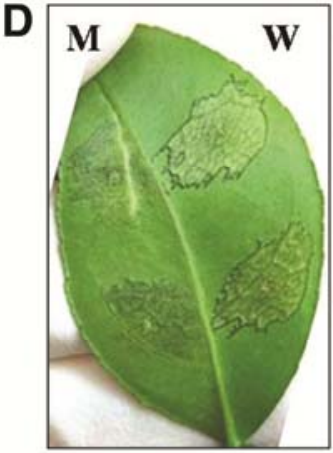

8 DPI

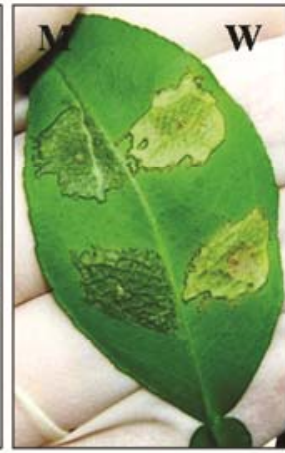

15 DPI

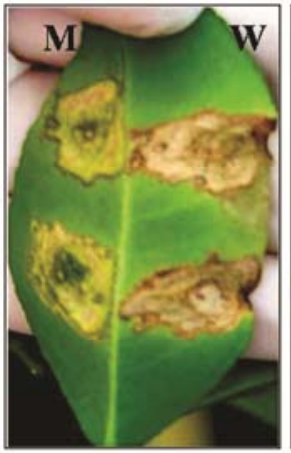

22 DPI

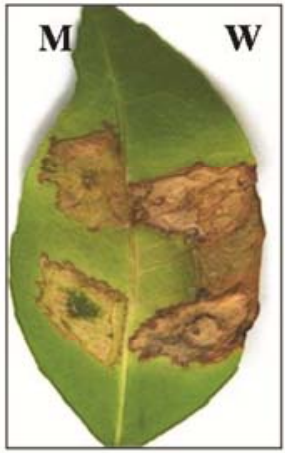

29 DPI

Fig. 3. The type II secretion system (T2SS) was involved in virulence in planta and the enzyme activity of protease and amylase in Xanthomonas citri subsp. citri. A, Arrows indicate gene location and direction in the T2SS gene cluster. Position and direction of flag indicate the insertion site of the transposon and direction of the kanamycin-resistance gene of EZ-Tn5, respectively. The red arrow represents the xps $D$ mutant used for assays of protease, amylase, and pathogenicity in this work. B, Protease and $\mathbf{C}$, amylase activity assays. Bacterial cells were inoculated on skim-milk plates and starch plates at a concentration of $10^{8} \mathrm{CFU} / \mathrm{ml}$. The results were photographed at 2 days postinoculation (dpi) for amylase activity and 3 dpi for protease activity. $\mathbf{D}$, Pathogenicity assay for the $x p s D$ mutant. The wild-type (W) and mutant (M) were inoculated into the leaves of grapefruit (Citrus paradise Macf. cv Duncan) at a concentration of $10^{6} \mathrm{CFU} / \mathrm{ml}$. Results were photographed at different timepoints as shown. 
gum mutants showed reduced water soaking in citrus leaves at an early stage after inoculation (data not shown), and the cell densities of the gum mutants were significantly reduced in grapefruit leaves as compared with those of the wild-type strain (Table 1). Interestingly, the surfaces of the leaves that were inoculated with the gum mutants formed canker lesions that were much thicker than those formed by the wild-type strain (symptom category IV) (Table 2).

In comparison to the extensively studied virulence function of EPS, our understanding of the role of LPS in virulence is rather limited with respect to plant-pathogen interactions. In the pre- sent study, four genes that are located in the LPS biosynthesis cluster were identified (Table 1). Among these four genes, the roles of $w z t, w z m$, and $r f b C$ in LPS biosynthesis and bacterial virulence have been reported previously (Cuthbertson et al. 2007; Laia et al. 2009; Li and Wang 2011; Wang et al. 2010). The fourth gene, XAC3599, encodes a small protein (65 amino acids) of unknown function and is absent from the lps cluster of other sequenced xanthomonads (Moreira et al. 2010), indicating that this gene is specific to the species $X$. citri subsp. citri. Mutations in XAC3599 caused fewer symptoms (category V) (Table 2 ) and significantly reduced cell density in host plants (Table 1).
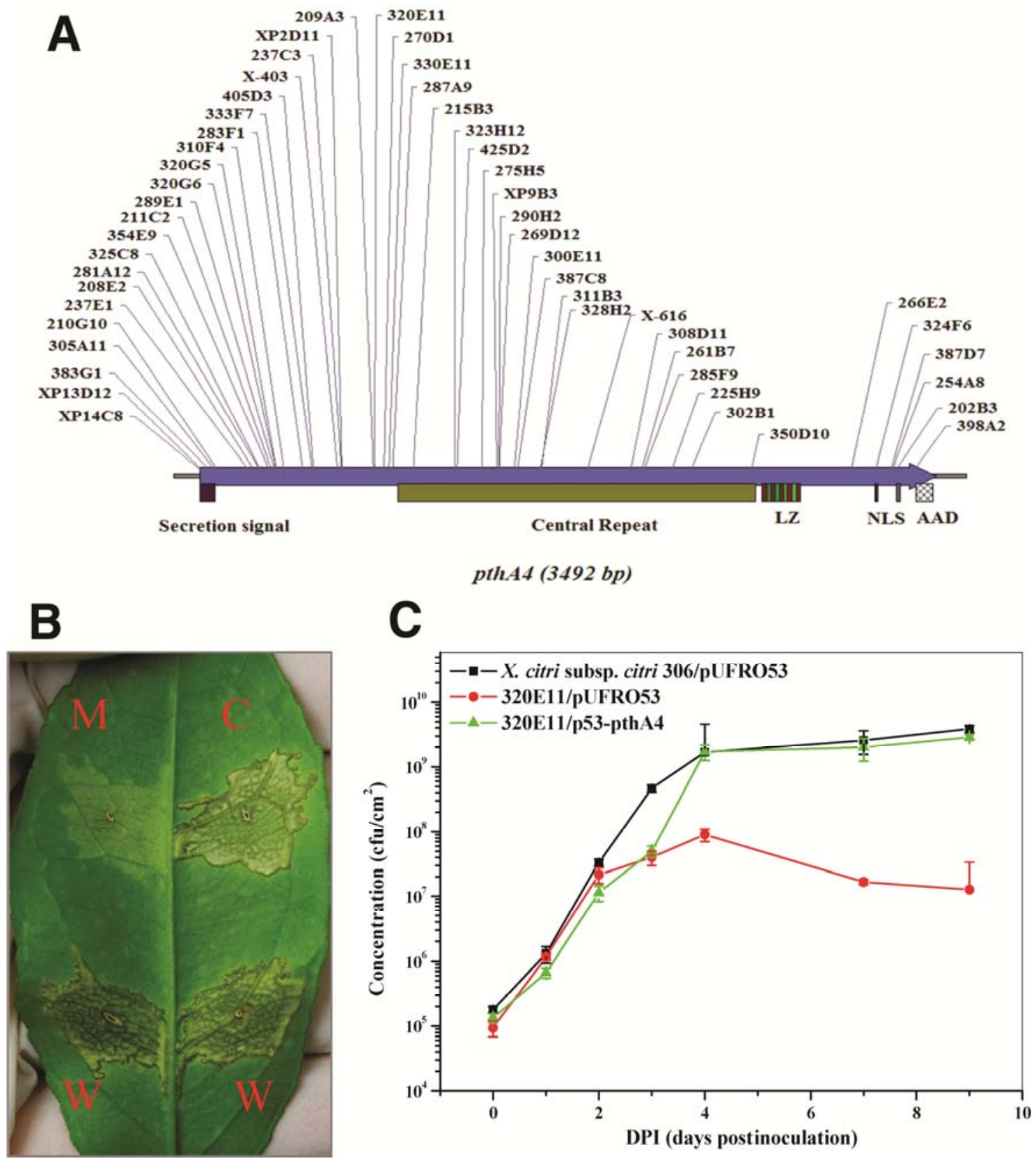

Fig. 4. The pthA4 gene was required for the pathogenicity of Xanthomonas citri subsp. citri. A, A total of 50 separate pthA mutants with EZ-Tn5 insertions in different positions were identified. Arrow indicates the open reading frame of $p t h A 4$ gene. Putative domains of the encoded protein are shown. LZ $=$ leucine zipper repeats, NLS = nuclear localization signals, AAD = acid activation domain. B, Pathogenicity assay. Bacterial cells were inoculated into the leaves of grapefruit (Citrus paradise Macf. cv Duncan) at a concentration of $10^{6} \mathrm{CFU} / \mathrm{ml}$. Results were photographed at 14 days after inoculation. All the pthA4 mutants showed similar symptoms in citrus plant. The symptoms caused by five randomly chosen mutants could be complemented to the wild type by the complementary plasmid p53-pthA4. Only the results of one mutant are shown. $\mathrm{W}=X$. citri subsp. citri 306/pUFR053, wild type containing empty vector; M = 320E11/pUFR053, pthA4 mutant containing empty vector; C = 320E11/p53-pthA4, mutant containing the complementary vector. C, Growth assay in planta. Bacterial cells were inoculated into grapefruit leaves at a concentration of $10^{6} \mathrm{CFU} / \mathrm{ml}$. Bacterial cells from the inoculated leaves were recovered at different timepoints, and the value represents means of three replicates. Means \pm standard deviation are plotted. 


\section{Transporters.}

In addition to the $w z m / w z t$ ATP-binding cassette (ABC) transporter system, eight genes (exbD1, rmrB, cydC, corA, $t a t B$, tat $C, y r b E$, and XAC2293) that encode diverse transporters were identified in our screening (Table 1). The exbDl gene is located in the TonB-dependent iron uptake cluster tonBexbB-exbD1-exbD2 (Wiggerich and Puhler 2000). Knockout of exbDl resulted in a loss of pathogenicity (symptom category I) in host plants, and the cell density inside the grapefruit leaves was more than 1,000-fold lower than that of wild type at $4 \mathrm{dpi}$. Furthermore, mutations in $t a t B$ and $t a t C$ of the $t a t A B C$ operon, which encodes the twin arginine translocation pathway, caused delayed symptoms (category IV) in grapefruit leaves. Compared with the wild-type pathogen, the cell density of the tatC mutant was more than 100-fold decreased, whereas no significant difference in the cell density of the tatB mutant was detected inside the grapefruit leaves at 4 dpi (Table 2). Additionally, mutations in $r m r B$, XAC2293, cydC, $\operatorname{cor} A$, and $y r b E$ caused fewer symptoms (category V) in host plants. Mutations in XAC2293 and corA caused a significant reduction in cell density, whereas mutations in $r m r B, c y d C$, and $y r b E$ had no significant effect on bacterial growth in grapefruit leaves at 4 dpi (Table 2).

\section{Hypothetical genes.}

As shown in Table 1, 16 hypothetical genes were identified in this study. Based on the bacterial growth assay in M9 medium, three genes (XAC1142, XAC1230, and XAC2357) were classified into the essential genes category and the other 13 genes were classified as putative virulence-related genes (Table 1). Mutations in 12 of these genes resulted in the formation of fewer symptoms (category V), and mutations in XAC1142 resulted in delayed symptom development (category IV) in grapefruit leaves after inoculation of the respective mutants.
Notably, mutant of XAC3049 caused no visible symptoms (category I) in host plant. The role of XAC3049 in pathogenicity was confirmed by complementation, using the XAC3049 gene cloned from the wild-type strain (X. F. Hu and N. Wang unpublished data). The mutant of XAC1496 formed only chlorosis (category II) in host plants, which was similar to the symptoms caused by the mutant of pthA4 (Table 2), indicating that this gene potentially played a critical role in the virulence of $X$. citri subsp. citri. XAC1230 was inserted by EZ-Tn5 in four separate mutants (Supplementary Fig. S2). Interestingly, these four mutants displayed varied phenotypes in planta. The mutants M1, M2, and M3 caused no symptoms in citrus leaves, and M4 caused only reduced symptoms. Similarly, M1, M2, and M3 were auxotrophic and M4 grew, albeit poorly, on minimal medium. To further confirm the phenotype of the XAC1230 mutation, the intact wild-type XAC1230 gene was cloned and was transformed into the four mutants. All of the complemented mutants rescued the virulence in planta and grew at wild-type rates on minimal medium. These results suggest that the XAC1230 gene underlies the phenotypic changes in pathogenicity and auxotrophy in $X$. citri subsp. citri.

\section{DISCUSSION}

Random mutagenesis using the Tn5-based strategy has been widely used to identify the genetic determinants that underlie the virulence mechanisms of various pathogenic bacteria. To investigate the genetic basis of the virulence mechanism of the citrus canker pathogen $X$. citri subsp. citri, an EZ-Tn5 mutant library containing approximately 22,000 mutants was screened for virulence-deficient mutants in the grapefruit host plant. These 22,000 mutants provided approximately fourfold excess coverage of the predicted 4,418 open reading frames (ORF) in the genome of $X$. citri subsp. citri (da Silva et al. 2002). All of
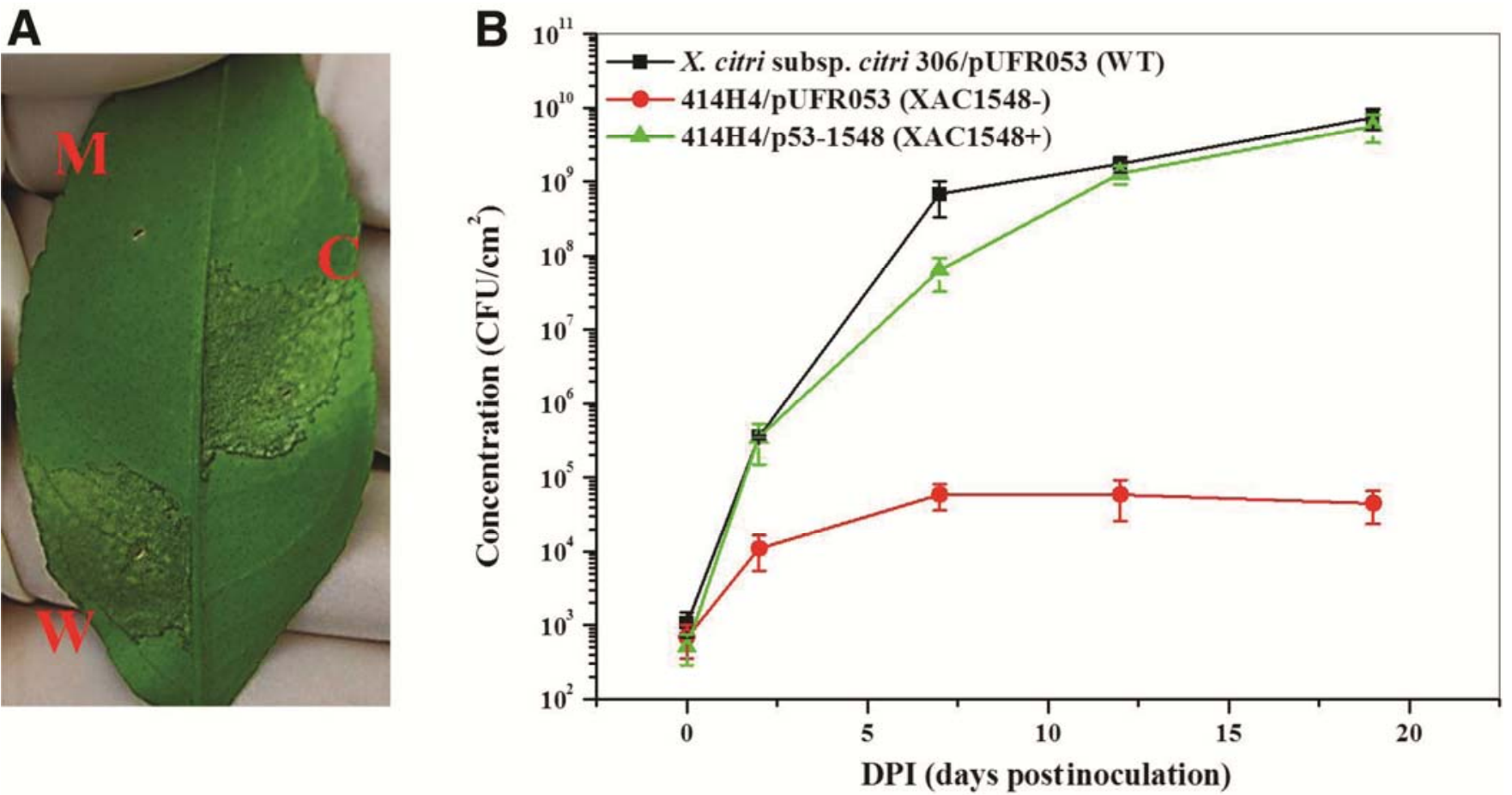

Fig. 5. The XAC1548 gene was required for the pathogenicity of Xanthomonas citri subsp. citri. A, Pathogenicity assay. Bacterial cells were inoculated into the leaves of grapefruit (Citrus paradise Macf. cv Duncan) at a concentration of $10^{6} \mathrm{CFU} / \mathrm{ml}$. Results were photographed at 12 days after inoculation. $\mathrm{W}=X$. citri subsp. citri 306/pUFR053, wild-type containing empty vector; $\mathrm{M}=414 \mathrm{H} 4 / \mathrm{pUFR} 053$, mutant of XAC1548 containing empty vector; $\mathrm{C}=414 \mathrm{H} 4 / \mathrm{p} 53$ 1548 , mutant containing the complementary vector. B, Growth assay in planta. Bacterial cells were inoculated into grapefruit leaves at a concentration of $10^{6}$ $\mathrm{CFU} / \mathrm{ml}$. Bacterial cells from the inoculated leaves were recovered at different timepoints, and the value represents means of three replicates. Means \pm standard deviation are plotted. 
the virulence-deficient mutants were verified with two cell concentrations of $10^{6}$ and $10^{8} \mathrm{CFU} / \mathrm{ml}$. An obvious insertion bias of EZ-Tn5 was noted in this study. For example, 50 separate pthA4 and 14 separate xpsD mutants were identified (Figs. 3 and 4). However, despite this bias in transposon insertions, 82 genes and 14 intergenic regions were identified as being involved in the virulence of $X$. citri subsp. citri, accounting for $2.22 \%$ of all genes in the complete genome. Among the 82 genes, 32 are known to be virulence-related in pathogenic bacteria and include genes encoding T2SS, T3SS, T3SS effectors, the quorum-sensing system, EPS or LPS, and general metabolic pathways. The identification of many previously identified virulence-related genes further validates the pathogenicity screening approach used in this work. A similar mutagenesis approach was recently employed to identify virulence-related genes in X. citri subsp. citri (Laia et al. 2009). In total, 3,300 mutants were screened using a pathogenicity assay in the host plant of Rangpur limes (C. limonia), and 35 genes were identified as being potentially involved in the virulence of this pathogen (Laia et al. 2009). Notably, the pthA mutation was not identified in their screen. Moreover, only three genes (cls, wzt, and $h r p M$ ) reported by Laia and associates (2009) overlapped with our results. This small degree of overlap between the two studies might be explained by two different citrus cultivars that were used for the pathogenicity assays; $C$. paradise Macf. cv. Duncan was used in this study, whereas $C$. limonia was used in the previous study (Laia et al. 2009). Alternatively, another important reason could be the genome coverage of the mutant libraries of both works. In all, 3,300 mutants and 22,000 mutants were screened by Laia and associates (2009) and in this work, respectively. The probability of finding one transposon insert for a certain gene were calculated for both libraries based on the calculated formula $P=1-(1-x / g)^{n}$, where $P$ is the probability of finding one transposon insert within a given gene, $x$ is the length of the gene $(1,000 \mathrm{bp}), g$ is the length of the genome $\left(5.27 \times 10^{6}\right.$ bp in $X$. citri subsp. citri), and $n$ is the number of transposon inserts present in the population (Krysan et al. 1999). The probability of finding one transposon insert for a certain gene with 22,000 mutants is $98.5 \%$, whereas it is $46.5 \%$ when 3,300 mutants are screened for $X$. citri subsp. citri (Laia et al. 2009). In the present study, the contribution to pathogenesis of nine genes, including four essential genes $(\operatorname{trp} G, \operatorname{trp} C, \operatorname{purD}$, and $\mathrm{XAC1230)}$ and five virulence-related genes ( $p$ thA4, hrpM, peh-1, XAC1548, and XAC3049), was confirmed by complementation with the respective wild-type gene (Table 1). We also validated the mutated genes and their phenotypes by analyzing the EZ-Tn5 insertion copy number using Southern blot analysis. Only one of 217 mutants contained two EZ-Tn5 insertions, and the rest contained one single-copy insertion, which is consistent with the low rate (less than $1 \%$ ) of multiple-copy transposon insertions that is described by the manufacturer of the EZ-Tn5 insertion kit that we used (Epicentre, Madison, WI, U.S.A.). Importantly, in addition to the 32 known virulence-related genes, 27 novel genes were identified in this work, which provides new insights into the genetic basis of $X$. citri subsp. citri pathogenicity.

To analyze the roles of different virulence factors, the identified virulence-related genes (excluding the essential genes) were discussed according to the diverse symptoms caused by the corresponding mutants as follows. On the basis of the changes exerted on the citrus leaves, the symptoms caused by the various mutants were classified into five categories. The mutated genes were assigned to their respective symptom categories (Table 2). Mutants in category I showed no pathogenicity in host plants, as no visible canker symptoms formed on the citrus leaves. The loss of pathogenicity of the T3SS mutants ( $h p a B$, hrcV, and $h r c N$ ) was primarily due to a failure of effector transloca- tion into the host cells. HpaB functions as a T3SS chaperone in $X$. campestris pv. vesicatoria and promotes the secretion of multiple effectors, including AvrBs3, and prevents the delivery of noneffectors into the plant cells (Büttner et al. 2004). The $\mathrm{HrcV}$ and $\mathrm{HrcN}$ proteins are conserved among animal and plant pathogenic bacteria and are part of the core secretion apparatus of T3SS (Lorenz and Buttner 2009).

Mutants of the pthA4 and XAC1496 genes caused only chlorosis in the host plant (classified as category II) (Table 2). After inoculation of the pthA4 mutant, the citrus leaves remained flat and no visible hypertrophy symptoms were observed at the inoculated area (Fig. 4B). This observation is consistent with previous reports that PthA was responsible for hyperplasia and hypertrophy of the citrus canker lesions (Duan et al. 1999; Swarup et al. 1991). Although a mutation of pthA4 caused significantly reduced bacterial growth, the mutant still multiplied within the intercellular spaces of the citrus leaves (Fig. 4C). Interestingly, although the cell density of the pthA4 mutant was 20-fold lower than that of the wild type, it was at least fivefold higher than that of the T3SS mutants (hpaB, $h r c V$, and $h r c N$ ) inside the grapefruit leaves (Table 1). Combined with the observation that all three T3SS mutants (hpaB, $h r c V$, and $h r c N$ ) caused no visible symptoms on the citrus leaves, it is likely that the chlorosis symptom of the pthA4 mutants was caused by other effectors of T3SS. Notably, X. citri subsp. citri 306 contains four pthA homologs named pthAl, pthA2, pthA3, and pthA4 on the two plasmids pXAC33 and pXAC64 (da Silva et al. 2002). Unlike the high mutation frequency of the pthA4 gene (in which 50 mutations were identified), no $p t h A 1$, pthA2, or pthA3 mutant was identified by our screen, implying a minor or dispensable role of these three pthA homologs in the virulence of the pathogen.

Mutations in gumK and gumF caused decreased water-soaking and thicker canker-lesion symptoms and were, therefore, assigned to category III (Table 2). Water soaking is one of the first macroscopic symptoms caused by many phytopathogens of xanthomonads such as $X$. axonopodis pv. manihotis (Kemp et al. 2004) and $X$. campestris pv. citrumelo (Swarup et al. 1991). The decreased water soaking caused by the gum mutations is consistent with a previous report in which an injection of bacterial EPS extract caused water soaking in the corresponding plant (El-Banoby and Rudolph 1979). In addition to mediating water soaking in the intercellular spaces, others roles for EPS have been suggested in epiphytic fitness and intercellular multiplication during the bacterial invasion of plants, including protecting the bacteria from desiccation, enhancing attachment to surfaces, reducing contact with environmental toxic compounds, and concentrating minerals and nutrients (Denny 1995). In the present study, growth of the gum mutants was significantly reduced relative to wild type (Table 1), which is consistent with a previous report that a mutation in $\operatorname{gumB}$ significantly reduced the growth of $X$. citri subsp. citri in C. limon leaves (Rigano et al. 2007).

Mutants that showed delayed symptom development in grapefruit leaves were classified into category IV (Table 2). For example, the T2SS gene mutants caused water soaking at an early stage after inoculation in the grapefruit leaves and the water soaking was followed by canker lesions that were similar to wild type. However, the development of canker symptoms was delayed by approximately one week relative to wild type (Fig. 3D). This result is consistent with the previous report that mutation of $x p s D$ affected cellulose degradation and virulence of $X$. citri subsp. citri (Baptista et al. 2010). T2SS is important for bacterial pathogenesis in both plants and animals (Cianciotto 2005; Johnson et al. 2006). A variety of hydrolytic enzymes are secreted via T2SS in Xanthomonas spp., including protease, amylase, pectate lyase, cellulase, and xylanase 
(Baptista et al. 2010; Furutani et al. 2004; Lee et al. 2004; Szczesny et al. 2010). Consistently, the extracellular activities of protease and amylase in the xps mutants ( $x p s D, x p s M, x p s N$, $x p s E, x p s F$ and $x p s G$ ) were much lower than that of the wildtype pathogen (Fig. 3B and C). The extracellular enzymes that are secreted via T2SS are known to contribute to the degradation of the plant cell wall, which is usually a major obstacle to bacterial invasion (McNeil et al. 1984). Citrus canker symptoms are associated with the leaf epidermis, which is composed of cell wall. Thus, T2SS and its substrates might contribute to canker symptom development by degrading the epidermal cell wall. Consequently, loss-of-function mutations in T2SS genes will delay the development of symptoms in grapefruit leaves. In addition, substrates of T2SS have been suggested to facilitate the assembly of extracellular T3SS appendages (Szczesny et al. 2010), which transport virulence effectors into host cells to suppress the plant's immune system and thereby promote disease progression.

Mutants in category $\mathrm{V}$ caused water-soaking and canker-lesion symptoms on the citrus leaves, but these symptoms were much milder as compared with wild type. The mechanisms of virulence deficiency in this category might be more complicated, as diverse functional genes were assigned to this category. Some mutated genes are involved in the synthesis of known virulence factors. For example, mutants of $w z t, w z m, r f b C$, and XAC3599 also showed less symptoms in citrus leaves (Table 2). These four genes are located in a gene cluster that underlies the production of LPS, which is the major component of bacterial outer membranes and is considered an important virulence factor of many plant bacterial pathogens, including Xanthomonas spp. (Berry et al. 2009; Dow et al. 1995; Drigues et al. 1985; Li and Wang 2011; Titarenko et al. 1997). Wzt and Wzm constitute an $\mathrm{ABC}$ transporter system for the exportation of the $\mathrm{O}$-antigen portion of LPS across the inner membrane of $E$. coli (Cuthbertson et al. 2007). RfbC contains two separate glycosyl transferase family 2 domains, which are involved in $\mathrm{O}$-antigen biosynthesis in a wide variety of bacteria ( $\mathrm{Li}$ and Wang 2011; P. G. Wang et al. 2008). Interestingly, XAC3599 is located in the same lps gene cluster, yet its function remains unknown. Mutations in four transporter genes $(\operatorname{cyd} d, \operatorname{cor} A, \operatorname{rmr} B$, and XAC2293) also caused fewer symptoms in grapefruit leaves. The $c y d C$ gene encodes an ATP-binding protein in the CydDC $\mathrm{ABC}$ transport system and is involved in the virulence of the animal pathogen of Shigella flexneri in a mouse model (Way et al. 1999). In E. coli, CydDC is required for proper membrane assembly of the cytochrome $b d$ complex (Pittman et al. 2002), which is one of the two principal membrane-bound terminal respiratory oxidases and is required for resistance to a variety of environmental stresses (Jünemann 1997). The cydC gene might play a similar role in the respiratory pathway of $X$. citri subsp. citri and, in turn, contribute to bacterial growth in planta. The product of the $\operatorname{cor} A$ gene forms a $\mathrm{Mg}^{2+}$ transportation channel that is the primary source of intracellular $\mathrm{Mg}^{2+}$ in Salmonella typhimurium (Lunin et al. 2006), and a strain lacking corA exhibited attenuated virulence upon injection in mice (Papp-Wallace et al. 2008). Consistent with our results, a virulence-deficient corA mutant was identified in a mutant library of $X$. albilineans in a sugarcane model (Rott et al. 2011). The role of corA in the virulence of Xanthomonas spp. has not yet been characterized and needs further study. The protein encoded by $r m r B$ contains 13 putative transmembrane domains and belongs to the major facilitator superfamily of efflux pump proteins. $r m r B$ (XAC0642) and the downstream gene XAC0641 (which encode a multidrug-resistance efflux pump) form a putative transcriptional unit, since the two ORF overlap with four nucleotides (da Silva et al. 2002). The RmrB protein has been proposed to prevent accumulation of toxic plant com- pounds inside bacterial cells, and an $\mathrm{rmrB}$ mutant in Rhizobium etli increased sensitivity to plant metabolites, including salicylic acid, phytoalexins, and flavonoids (González-Pasayo and Martínez-Romero 2000). RmrB likely plays similar roles in $X$. citri subsp. citri. In addition to the mutants described above, mutants of 12 hypothetical genes also showed deficient virulence (symptom category $\mathrm{V}$ ) in host plants, and those genes will be discussed later.

Bacteria need to coordinate their limited genetic resources and their diverse virulence factors to survive harsh environments, including the intercellular spaces in host plants. In our screen, four regulatory genes ( $r p f C, d k s A, \mathrm{XAC1548, \text {and }}$ XAC2670) were identified as being potentially involved in the virulence regulation of $X$. citri subsp. citri (Table 1 ).

The DSF-mediated $r p f$ quorum-sensing system was wellstudied in $X$. campestris pv. campestris and regulates the synthesis of extracellular enzymes, EPS production, and biofilm formation and is also required for full virulence in host plants (He and Zhang 2008). A set of target proteins were found to directly interact with the quorum-sensing regulator RpfG of $X$. citri subsp. citri (Andrade et al. 2006), including HmsF. Insertion of EZ-Tn5 in $h m s F$ has a potential polar effect on the expression of downstream genes of the hmsHFRS operon (Table 1). The $h m s F$ gene encodes a putative polysaccharide deacetylase, and the products of the $h m s$ operon are required for the biofilm formation of Yersinia pestis (Forman et al. 2006). It is likely that the reduced virulence and cell density of the $h m s F$ mutant in planta resulted from its effect on biofilm formation through its direct interaction with RpfG, since RpfG is the regulator for the DSF signaling pathway.

The putative protein that is encoded by XAC2670 shares high similarity ( $81 \%$ in amino acid sequence) to the TCRS sensor AlgZ (also called FimS) in P. aeruginosa. This sensor might interact with the cognate regulator $\mathrm{AlgR}$ and has been reported to be both a repressor of alginate biosynthesis (Yu et al. 1997) and an activator of type IV pili-mediated twitching motility (Whitchurch et al. 1996, 2002). Interestingly, XAC2670 is located adjacent to a gene cluster (XAC2664 to XAC2669) that is responsible for type IV pili assembly, which suggests a potential role for XAC2670 in the regulation of type IV pili, which are principal structures for host colonization and adhesion in many pathogenic bacteria (Craig et al. 2004). Mutation of pilC or pilB has been shown to cause significant reduction of virulence in $X$. campestris pv. campestris (Qian et al. 2005).

XAC1548 encodes a putative GntR family regulator that is named after the B. subtilis repressor of the gluconate operon (Haydon and Guest 1991). Regulators of this family share a conserved N-terminal DNA binding domain, but one or both of the C-terminal effector binding and oligomerization domains is quite diverse and heterogeneous (Rigali et al. 2002). As a consequence of this heterogeneity, the GntR regulators have been further classified into six subfamilies, FadR, HutC, MocR, YtrA, AraR, and PlmA (Lee et al. 2003; Rigali et al. 2004). Homolog analysis showed that the protein encoded by XAC1548 belongs to the YtrA subfamily, which contains a reduced C-terminal domain. The ytrA gene, which is a part of a self-regulated operon, has been experimentally explored in B. subtilis. This operon consists of genes encoding an $\mathrm{ABC}$ transporter system that is involved in acetoin utilization (Yoshida et al. 2000). Interestingly, XAC1548 is the first gene in a putative operon that contains nodI (XAC1547) and the three hypothetical genes XAC1546, XAC1545, and XAC1544. The nodI gene encodes a putative ABC transporter ATP-binding protein, and knockout of a homolog nodI in R. leguminosarum resulted in a "nodulation-delayed" phenotype in pea host plants (Evans and Downie 1986). Moreover, XAC1546 en- 
codes a putative $\mathrm{ABC}$ transporter system permease protein. It is likely that $\mathrm{XAC} 1548$ contributes to virulence by regulating the ABC transporter system that is encoded by XAC1544, XAC1545, XAC1546, and XAC1547. Further characterization of XAC1548 and the ABC transporter system is needed to fully understand their roles in the virulence of $X$. citri subsp. citri.

Importantly, we identified 13 hypothetical genes that were classified into putative virulence-related genes in the present study. Most of these hypothetical genes have no significant homology with known virulence genes. Thus, the identification of these novel virulence genes will be important for increasing our understanding of the virulence mechanism of $X$. citri subsp. citri and other foliar bacterial pathogens, even though further characterization of those hypothetical genes is necessary. For example, the putative protein encoded by the hypothetical gene XAC1142 contains a PrpF domain. PrpF was recently characterized as a non-PLP (pyridoxal-5-phosphate) dependent isomerase that is involved in the catabolism of propionate (Garvey et al. 2007). Propionate is a shortchain fatty acid that is commonly used as a food preservative because of its broad negative effects on cellular functions (Eklund 1980). Interestingly, this bacteria-toxic compound is present in citrus plants (Moshonas and Shaw 1983). XAC1142 might play a similar role in protecting the pathogen against the toxicity of propionate, which is consistent with our observed reduction of cell density of the XAC1142 mutant in planta (Table 1).

In conclusion, we have significantly advanced the understanding of the putative genetic determinants of the virulence mechanism of $X$. citri subsp. citri by identifying 59 putative virulence-related genes, including 27 novel genes. Further characterization of the putative virulence-related genes is needed. Characterization of the roles of these genes in mediating citrus canker disease progression will facilitate the design of new strategies for controlling citrus canker and other foliar bacterial diseases.

\section{MATERIALS AND METHODS}

\section{Bacterial strains, growth conditions and plasmids.}

The wild-type strain of X. citri subsp. citri 306 was provided by the Division of Plant Industry of the Florida Department of Agriculture and Consumer Services, Gainesville, FL, U.S.A. The $X$. citri subsp. citri strains were cultured at $28^{\circ} \mathrm{C}$ in nutrient broth (Difco, Detroit), on NA (Difco) plates, or on M9 minimal medium plates (Sambrook and Russell 2001). The $E$. coli strain was cultured at $37^{\circ} \mathrm{C}$ in Luria-Bertani (LB) medium. When required, the growth media were supplemented with ampicillin $\left(50 \mu \mathrm{g} \mathrm{ml}^{-1}\right)$, chloramphenicol $\left(20 \mu \mathrm{g} \mathrm{ml}^{-1}\right)$, gentamycin $\left(5 \mu \mathrm{g} \mathrm{ml}^{-1}\right)$, kanamycin $\left(50 \mu \mathrm{g} \mathrm{ml}^{-1}\right)$, and rifamy$\operatorname{cin}\left(50 \mu \mathrm{g} \mathrm{ml} \mathrm{m}^{-1}\right)$.

\section{Screening of the mutant library \\ of the $X$. citri subsp. citri in grapefruit.}

The mutant library of $X$. citri subsp. citri was constructed previously (Guo et al. 2010). A total of approximately 22,000 independent mutants were subjected to the pathogenicity test for screening for virulence-deficient mutants. The EZ-Tn5 mutants were stored at $-80^{\circ} \mathrm{C}$ and were cultured on NA plates containing kanamycin. The pathogenicity assays of the mutants were performed as previously described (Yan and Wang 2011). Briefly, fully expanded, immature grapefruit ( $C$. paradise Macf. cv. Duncan) leaves were prepared in a quarantine greenhouse facility at the Citrus Research and Education Center, Lake Alfred, FL, U.S.A. The $X$. citri subsp. citri strains were cultured for 2 days on NA plates at $28^{\circ} \mathrm{C}$ and were resuspended in sterile tap water. For each mutant, two bacterial suspensions $\left(10^{6}\right.$ and $\left.10^{8} \mathrm{CFU} / \mathrm{ml}\right)$ were injected into the intercellular spaces of the leaves with a needleless syringe. For each concentration, the cell suspension was inoculated into two independent leaves with two inoculation sites on each leaf. The wild-type pathogen was inoculated into the same leaves at the same cell suspension concentration. All of the tests were repeated three times with similar results. Similar canker symptoms could be induced by inoculating the wild-type pathogen at concentrations of either $10^{6}$ or $10^{8}$ $\mathrm{CFU} / \mathrm{ml}$. The disease progression with an inoculation of $10^{6}$ $\mathrm{CFU} / \mathrm{ml}$ was delayed by approximately 7 days compared with the higher inoculation concentration of $10^{8} \mathrm{CFU} / \mathrm{ml}$ (data not shown). Only the symptoms induced by the pathogen with an inoculation of $10^{6} \mathrm{CFU} / \mathrm{ml}$ were present.

\section{Growth assays in planta.}

The $X$. citri subsp. citri strains were cultured on NA plates for 2 days at $28^{\circ} \mathrm{C}$. The bacterial cells were resuspended in sterile tap water at a concentration of $10^{6} \mathrm{CFU} / \mathrm{ml}$ and were infiltrated into the grapefruit leaves with a needleless syringe. To evaluate the growth of wild-type $X$. citri subsp. citri strain 306 and its derivatives in the intercellular spaces of the plants, leaf disks (with a leaf area of $1 \mathrm{~cm}^{2}$ ) from inoculated leaves (four leaves for each sample) were excised with a cork borer and were then ground in $1 \mathrm{ml}$ of sterile tap water. The samples were serially diluted and were plated on NA plates with appropriate antibiotics. The bacterial colonies were counted following incubation at $28^{\circ} \mathrm{C}$ for 3 days. The in planta growth was measured in quadruplicate, and the assays were repeated three times with similar results.

\section{Southern blot analysis.}

Genomic DNA from the mutant strains was extracted using a genomic DNA purification kit (Promega, Madison, WI, U.S.A.), and $3 \mu \mathrm{g}$ of genomic DNA was digested with EcoRI overnight at $37^{\circ} \mathrm{C}$ and was subjected to electrophoresis on a $0.7 \%$ agarose gel. The DNA was transferred to a positively charged nylon membrane (Roche, Indianapolis, IN, U.S.A.), using a standard protocol. Probe generation, hybridization, and chemiluminescence detection were performed using the Digoxigenin-High Prime II DNA labeling and detection starter kit according to the manufacturer's instructions (Roche, Indianapolis, IN, U.S.A.).

\section{Identification of the EZ-Tn5 insertion sites of the $X$. citri subsp. citri mutants.}

Rescue cloning was performed to determine the insertion sites of the EZ-Tn5 transposon in the mutants according to the manufacturer's instructions (Epicentre). In brief, $1 \mu \mathrm{g}$ of genomic DNA of the mutants of interest was digested with Pst or EcoRI overnight at $37^{\circ} \mathrm{C}$. The digested DNA was purified, self-ligated, and transformed into the E. coli strain EC100D by electroporation. The transformed cells were spread onto LB plates containing kanamycin and were incubated overnight at $37^{\circ} \mathrm{C}$. At least three separate kanamycin-resistant colonies were subjected to plasmid extraction for each mutant. The plasmid was sequenced using the primer R6KAN-2 RP-1 (Epicentre). BLAST analyses and alignment with the genomic sequence of $X$. citri subsp. citri 306 were performed to determine the insertion site of the EZ-Tn5 transposon.

For the identified genes located in potential operons, polarity analyses were conducted to determine if the insertion of EZ-Tn5 caused polar effect on the downstream genes in the operons, following the instructions of the kit (Epicentre). Briefly, the insertion of EZ-Tn5 has a potential polar effect on the expression of one or more of the downstream genes, if the 
direction of the kanamycin-resistance gene of EZ-Tn5 is different from that of the mutated gene. The insertion of EZ-Tn5 has no polar effect on the expression of one or more downstream genes if their directions are same.

\section{Construction of complementary plasmids.}

The polymerase chain reaction (PCR) primers used for the amplification of target genes are listed in Supplementary Table $\mathrm{S} 2$. To construct the complementary plasmid for $p t h A 4$, the megaplasmids of $X$. citri subsp. citri 306 were extracted and digested with KpnI and $X h o I$ and were then ligated into the pBluescript II $\mathrm{SK}(+)$ plasmid (Invitrogen, Carlsbad, CA, U.S.A.). The resulting plasmids were sequenced to select the plasmid that contained the 16-kb KpnI-XhoI fragment harboring the pthA4 gene. This plasmid was named pBS-A4. Using the primers pthA4F and pthA4R and pBS-A4 as the template, a PCR fragment of 3,896 bp containing the pthA4 gene was amplified and inserted into the T-vector of pCR2.1 (Invitrogen). The resulting plasmid (p2.1-pthA4) was digested with EcoRI and HindIII and was ligated with pUFR053 (El Yacoubi et al. 2007) to yield the complementary plasmid p53-pthA4. To generate the complementary plasmid of p53-0478, the intact $\operatorname{trp} G$ gene was amplified using the primers $0478 \mathrm{~F}$ and $0478 \mathrm{R}$ and the genomic DNA of X. citri subsp. citri 306 as the template. The PCR product was digested with SacI and HindIII and was ligated into pUFR053 to yield the plasmid p53-0478. The complementary plasmids p53-0481, p53-0511, p53-0618, p53-0661, p53-1548, and p53-1230 were constructed using a similar approach with their respective primers. The complementary plasmids and the empty vector pUFR053 were transformed into the corresponding mutants.

\section{Auxotrophic, protease, and amylase assays.}

M9 medium was used to test whether the $X$. citri subsp. citri mutants were auxotrophic on minimal medium. In brief, the mutants and the wild type were initially cultured on NA plates for 2 days, and then, the bacteria were restreaked on M9 medium plates and were cultured at $28^{\circ} \mathrm{C}$. The growth of the bacteria was measured over the following 5 days after inoculation. For each assay, three replicates were used.

Bacterial protease activity was assayed on skim-milk plates. The bacterial cells of wild type and xps mutant strains were collected from NA plates and were resuspended in sterile water at a concentration of $10^{8} \mathrm{CFU} / \mathrm{ml}$, and then, $2 \mu \mathrm{l}$ of the cell suspension was inoculated on a skim-milk plate and was cultured at $28^{\circ} \mathrm{C}$. The protease activity of wild type and mutant strains was observed and photographed 3 dpi.

For the amylase assay, the bacterial cells of wild type and xps mutant strains were collected from NA plates and were resuspended in sterile water at a concentration of $10^{8} \mathrm{CFU} / \mathrm{ml}$, and $2 \mu \mathrm{l}$ of the cell suspension was then inoculated on a NA plate containing $1 \%$ (wt/vol) starch and was cultured at $28^{\circ} \mathrm{C}$. The plates were stained using Gram's iodine solution (containing 0.5 and $1 \mathrm{~g}$ of potassium iodide in $100 \mathrm{ml}$ of water) at 2 dpi, and the results were photographed after staining.

\section{Public software used \\ for the analyses performed in this work.}

The National Center for Biotechnology Information database was used to determine the insertion site of EZ-Tn5 in all mutants obtained in this work. The J. Craig Venter Institute database was used to analyze the functional categories of all of the genes that were identified in this work. The KEGG database was used to analyze the general metabolic pathways of the genes of interest that were identified in this work. The SMART database was used to analyze the one or more functional domains of the genes that were identified in this work.

\section{ACKNOWLEDGMENTS}

This work was supported by the United States Department of Agriculture National Institute of Food and Agriculture Special Citrus Canker Grant Project 94430. We thank L. Yang and V. Kolbasov for their technical assistance.

\section{LITERATURE CITED}

Alegria, M. C., Docena, C., Khater, L., Ramos, C. H. I., da Silva, A. C. R., and Farah, C. S. 2004. New protein-protein interactions identified for the regulatory and structural components and substrates of the type III secretion system of the phytopathogen Xanthomonas axonopodis pathovar citri. J. Bacteriol. 186:6186-6197.

Andrade, M. O., Alegria, M. C., Guzzo, C. R., Docena, C., Pareda Rosa, M. C., Ramos, C. H. I., and Farah, C. S. 2006. The HD-GYP domain of RpfG mediates a direct linkage between the Rpf quorum-sensing pathway and a subset of diguanylate cyclase proteins in the phytopathogen Xanthomonas axonopodis pv. citri. Mol. Microbiol. 62:537-551.

Baptista, J. C., Machado, M. A., Homem, R. A., Torres, P. S., Vojnov, A. A., and Amaral, A. M. 2010. Mutation in the xpsD gene of Xanthomonas axonopodis pv. citri affects cellulose degradation and virulence. Genet. Mol. Biol. 33:146-153.

Berry, M. C., McGhee, G. C., Zhao, Y., and Sundin, G. W. 2009. Effect of a waaL mutation on lipopolysaccharide composition, oxidative stress survival, and virulence in Erwinia amylovora. FEMS Microbiol. Lett. 291:80-87.

Brunings, A., and Gabriel, D. 2003. Xanthomonas citri: breaking the surface. Mol. Plant Pathol. 4:141-157.

Büttner, D., and Bonas, U. 2010. Regulation and secretion of Xanthomonas virulence factors. FEMS Microbiol. Rev. 34:107-133.

Büttner, D., Gürlebeck, D., Noel, L. D., and Bonas, U. 2004. HpaB from Xanthomonas campestris pv. vesicatoria acts as an exit control protein in type III-dependent protein secretion. Mol. Microbiol. 54:755-768.

Cianciotto, N. P. 2005. Type II secretion: a protein secretion system for all seasons. Trends Microbiol. 13:581-588.

Civerolo, E. 1984. Bacterial canker disease of citrus. J. Rio Grande Val. Hortic. Soc 37:127-146.

Craig, L., Pique, M. E., and Tainer, J. A. 2004. Type IV pilus structure and bacterial pathogenicity. Nat. Rev. Microbiol. 2:363-378.

Cubero, J., and Graham, J. 2002. Genetic relationship among worldwide strains of Xanthomonas causing canker in citrus species and design of new primers for their identification by PCR. Appl. Environ. Microbiol. 68:1257-1264.

Cuthbertson, L., Kimber, M., and Whitfield, C. 2007. Substrate binding by a bacterial ABC transporter involved in polysaccharide export. Proc. Natl. Acad. Sci. U.S.A. 104:19529-19534.

da Silva, A., Ferro, J., Reinach, F., Farah, C., Furlan, L., Quaggio, R., Monteiro-Vitorello, C., Van Sluys, M., Almeida, N., and Alves, L. 2002. Comparison of the genomes of two Xanthomonas pathogens with differing host specificities. Nature 417:459-463.

Denny, T. 1995. Involvement of bacterial polysaccharides in plant pathogenesis. Annu. Rev. Phytopathol. 33:173-197.

Dow, J. M., Osbourn, A. E., Wilson, T. J. G., and Daniels, M. J. 1995. A locus determining pathogenicity of Xanthomonas campestris is involved in lipopolysaccharide biosynthesis. Mol. Plant-Microbe Interact. 8:768777.

Drigues, P., Demery-Lafforgue, D., Trigalet, A., Dupin, P., Samain, D., and Asselineau, J. 1985. Comparative studies of lipopolysaccharide and exopolysaccharide from a virulent strain of Pseudomonas solanacearum and from three avirulent mutants. J. Bacteriol. 162:504-509.

Duan, Y., Castaneda, A., Zhao, G., Erdos, G., and Gabriel, D. 1999. Expression of a single, host-specific, bacterial pathogenicity gene in plant cells elicits division, enlargement, and cell death. Mol. Plant-Microbe Interact. 12:556-560.

Dunger, G., Relling, V., Tondo, M., Barreras, M., Ielpi, L., Orellano, E., and Ottado, J. 2007. Xanthan is not essential for pathogenicity in citrus canker but contributes to Xanthomonas epiphytic survival. Arch. Microbiol. 188:127-135.

Eklund, T. 1980. Inhibition of growth and uptake processes in bacteria by some chemical food preservatives. J. Appl. Microbiol. 48:423-432.

El-Banoby, F., and Rudolph, K. 1979. Induction of water-soaking in plant leaves by extracellular polysaccharides from phytopathogenic pseudomonads and xanthomonads. Physiol. Plant Pathol. 15:341-346.

El Yacoubi, B., Brunings, A., Yuan, Q., Shankar, S., and Gabriel, D. 2007. In planta horizontal transfer of a major pathogenicity effector gene. Appl. Environ. Microbiol. 73:1612-1621.

Evans, I., and Downie, J. 1986. The nodI gene product of Rhizobium leguminosarum is closely related to ATP-binding bacterial transport pro- 
teins; nucleotide sequence analysis of the nodI and nodJ genes. Gene 43:95-101.

Forman, S., Bobrov, A., Kirillina, O., Craig, S., Abney, J., Fetherston, J., and Perry, R. 2006. Identification of critical amino acid residues in the plague biofilm Hms proteins. Microbiology 152:3399-3410.

Furutani, A., Tsuge, S., Ohnishi, K., Hikichi, Y., Oku, T., Tsuno, K., Inoue, Y., Ochiai, H., Kaku, H., and Kubo, Y. 2004. Evidence for HrpXo-dependent expression of type II secretory proteins in Xanthomonas oryzae pv. oryzae. J. Bacteriol. 186:1374-1380.

Garvey, G. S., Rocco, C. J., Escalante-Semerena, J. C., and Rayment, I. 2007. The three-dimensional crystal structure of the PrpF protein of Shewanella oneidensis complexed with trans-aconitate: Insights into its biological function. Protein Sci. 16:1274-1284.

González-Pasayo, R., and Martínez-Romero, E. 2000. Multiresistance genes of Rhizobium etli CFN42. Mol. Plant-Microbe Interact. 13:572577.

Gottwald, T. R., Graham, J. H., and Schubert, T. S. 2002. Citrus canker: The pathogen and its impact. Plant Health Prog. doi:10.1094/PHP2002-0812-01-RV.

Graham, J. H., Gottwald, T. R., Cubero, J., and Achor, D. S. 2004. Xanthomonas axonopodis pv. citri: factors affecting successful eradication of citrus canker. Mol. Plant Pathol. 5:1-15.

Guo, Y., Sagaram, U. S., Kim, J. S., and Wang, N. 2010. Requirement of the galU gene for polysaccharide production by and pathogenicity and growth in planta of Xanthomonas citri subsp. citri. Appl. Environ. Microbiol. 76:2234-2242.

Guo, Y., Figueiredo, J. F., Jones, J., and Wang, N. 2011. HrpG, together with HrpX, play global roles in coordinating different virulence traits of Xanthomonas axonopodis pv. citri. Mol. Plant-Microbe Interact. 24:649-661.

Haydon, D. J., and Guest, J. R. 1991. A new family of bacterial regulatory proteins. FEMS Microbiol. Lett. 79:291-295.

Hayes, F. 2003. Toxins-Antitoxins: Plasmid Maintenance, Programmed Cell Death, and Cell Cycle Arrest. Science 301:1496-1499.

He, Y. W., and Zhang, L. H. 2008. Quorum sensing and virulence regulation in Xanthomonas campestris. FEMS Microbiol. Rev. 32:842-857.

Johnson, T. L., Abendroth, J., Hol, W. G. J., and Sandkvist, M. 2006. Type II secretion: from structure to function. FEMS Microbiol. Lett. 255:175-186.

Jude, F., Kohler, T., Branny, P., Perron, K., Mayer, M. P., Comte, R., and Van Delden, C. 2003. Posttranscriptional control of quorum-sensing-dependent virulence genes by DksA in Pseudomonas aeruginosa. J. Bacteriol. 185:3558.

Jünemann, S. 1997. Cytochrome $b d$ terminal oxidase. Biochim. Biophys. Acta 1321:107-127.

Kemp, B. P., Horne, J., Bryant, A., and Cooper, R. M. 2004. Xanthomonas axonopodis pv. manihotis gumD gene is essential for EPS production and pathogenicity and enhances epiphytic survival on cassava (Manihot esculenta). Physiol. Mol. Plant Pathol. 64:209-218.

Kingsley, M., Gabriel, D., Marlow, G., and Roberts, P. 1993. The opsX locus of Xanthomonas campestris affects host range and biosynthesis of lipopolysaccharide and extracellular polysaccharide. J. Bacteriol. 175:5839-5850

Krysan, P. J., Young, J. C., and Sussman, M. R. 1999 T-DNA as an insertional mutagen in Arabidopsis. Plant Cell 11:2283-2290

Laia, M., Moreira, L., Dezajacomo, J., Brigati, J., Ferreira, C., Ferro, M. Silva, A., Ferro, J., and Oliveira, J. 2009. New genes of Xanthomonas citri subsp. citri involved in pathogenesis and adaptation revealed by a transposon-based mutant library. BMC Microbiol. 9:12.

Lee, H. M., Chen, J. R., Lee, H. L., Leu, W. M., Chen, L. Y., and Hu, N. T. 2004. Functional dissection of the XpsN (GspC) protein of the Xanthomonas campestris pv. campestris type II secretion machinery. J. Bacteriol. 186:2946-2955.

Lee, M. H., Scherer, M., Rigali, S., and Golden, J. W. 2003. PlmA, a new member of the GntR family, has plasmid maintenance functions in Anabaena sp. strain PCC 7120. J. Bacteriol. 185:4315-4325.

Leigh, J. A., and Coplin, D. L. 1992. Exopolysaccharides in plant-bacterial interactions. Annu. Rev. Microbiol. 46:307-346.

Li, J., and Wang, N. 2011. The wxacO gene of Xanthomonas citri subsp. citri encodes a protein with a role in lipopolysaccharide biosynthesis, biofilm formation, stress tolerance and virulence. Mol. Plant Pathol. 12:381-396.

Lorenz, C., and Buttner, D. 2009. Functional characterization of the type III secretion ATPase $\mathrm{HrcN}$ from the plant pathogen Xanthomonas campestris pv. vesicatoria. J. Bacteriol. 191:1414-1428.

Lunin, V. V., Dobrovetsky, E., Khutoreskaya, G., Zhang, R., Joachimiak, A., Doyle, D. A., Bochkarev, A., Maguire, M. E., Edwards, A. M., and Koth, C. M. 2006. Crystal structure of the CorA $\mathrm{Mg}^{2+}$ transporter. Nature 440:833-837.

McNeil, M., Darvill, A. G., Fry, S. C., and Albersheim, P. 1984. Structure and function of the primary cell walls of plants. Annu. Rev. Biochem. 53:625-663.

Mogull, S. A., Runyen-Janecky, L. J., Hong, M., and Payne, S. M. 2001. $d k s A$ is required for intercellular spread of Shigella flexneri via an RpoS-independent mechanism. Infect. Immun. 69:5742.

Moreira, L., Almeida, N., Potnis, N., Digiampietri, L., Adi, S., Bortolossi, J., da Silva, A. C., da Silva, A. M., de Moraes, F., and de Oliveira, J. 2010. Novel insights into the genomic basis of citrus canker based on the genome sequences of two strains of Xanthomonas fuscans subsp. aurantifolii. BMC Genomics 11:238.

Moshonas, M. G., and Shaw, P. E. 1983. Composition of aqueous essence and essence oil from Citrus temple. J. Agric. Food Chem. 31:334-336.

Papp-Wallace, K. M., Nartea, M., Kehres, D. G., Porwollik, S., McClelland, M., Libby, S. J., Fang, F. C., and Maguire, M. E. 2008. The CorA $\mathrm{Mg}^{2+}$ channel is required for the virulence of Salmonella enterica serovar Typhimurium. J. Bacteriol.:6517-6523.

Paul, B. J., Barker, M. M., Ross, W., Schneider, D. A., Webb, C., Foster, J. W., and Gourse, R. L. 2004. DksA: a critical component of the transcription initiation machinery that potentiates the regulation of rRNA promoters by ppGpp and the initiating NTP. Cell 118:311-322.

Pittman, M. S., Corker, H., Wu, G., Binet, M. B., Moir, A. J. G., and Poole, R. K. 2002. Cysteine is exported from the Escherichia coli cytoplasm by CydDC, an ATP-binding cassette-type transporter required for cytochrome assembly. J. Biol. Chem. 277:49841-49849.

Pugsley, A. P. 1993. The complete general secretory pathway in gramnegative bacteria. Microbiol. Mol. Biol. Rev. 57:50-108.

Qian, W., Jia, Y., Ren, S., He, Y., Feng, J., Lu, L., Sun, Q., Ying, G., Tang, D., and Tang, H. 2005. Comparative and functional genomic analyses of the pathogenicity of phytopathogen Xanthomonas campestris pv. campestris. Genome Res. 15:757-767.

Qian, W., Han, Z.-J., and He, C. 2008. Two-component signal transduction systems of Xanthomonas spp.: a lesson from genomics. Mol. PlantMicrobe Interact. 21:151-161.

Rigali, S., Derouaux, A., Giannotta, F., and Dusart, J. 2002. Subdivision of the helix-turn-helix GntR family of bacterial regulators in the FadR, HutC, MocR, and YtrA subfamilies. J. Biol. Chem. 277:12507-12515.

Rigali, S., Schlicht, M., Hoskisson, P., Nothaft, H., Merzbacher, M., Joris, B., and Titgemeyer, F. 2004. Extending the classification of bacterial transcription factors beyond the helix-turn-helix motif as an alternative approach to discover new cis/trans relationships. Nucleic Acids Res. 32:3418-3426.

Rigano, L., Siciliano, F., Enrique, R., Sendín, L., Filippone, P., Torres, P., Qüesta, J., Dow, J., Castagnaro, A., and Vojnov, A. 2007. Biofilm formation, epiphytic fitness, and canker development in Xanthomonas axonopodis pv. citri. Mol. Plant-Microbe Interact. 20:1222-1230.

Rott, P. C., Fleites, L., Marlow, G., Rouer, M., and Gabriel, D. W. 2011. Identification of new candidate pathogenicity factors in the xylem-invading pathogen Xanthomonas albilineans by transposon mutagenesis. Mol. Plant-Microbe Interact. 24:594-605

Sambrook, J., and Russell, D. W. 2001. Molecular cloning: a laboratory manual. 3rd ed. Cold Spring Harbor Laboratory Press. Cold Spring Harbor, NY, U.S.A.

Szczesny, R., Jordan, M., Schramm, C., Schulz, S., Cogez, V., Bonas, U., and Büttner, D. 2010. Functional characterization of the Xcs and Xps type II secretion systems from the plant pathogenic bacterium Xanthomonas campestris pv. vesicatoria. New Phytol. 187:983-1002.

Siciliano, F., Torres, P., Sendín, L., Bermejo, C., Filippone, P., Vellice, G. Ramallo, J., Castagnaro, A., Vojnov, A., and Marano, M. 2006. Analysis of the molecular basis of Xanthomonas axonopodis pv. citri pathogenesis in Citrus limon. Electron. J. Biotechnol. 9:200-204.

Stall, R. E., and Seymour, C. P. 1983. Canker, a threat to citrus in the GulfCoast states. Plant Dis. 67:581-585.

Subramoni, S., Jha, G., and Sonti, R. 2006. Plant-Associated Bacteria: Virulence functions of xanthomonads. 535-571. Springer. The Netherland.

Swarup, S., De Feyter, R., Brlansky, R., and Gabriel, D. 1991. A pathogenicity locus from Xanthomonas citri enables strains from several pathovars of $X$. campestris to elicit cankerlike lesions on citrus. Phytopathology 81:802-809.

Swarup, S., Yang, Y., Kingsley, M., and Gabriel, D. 1992. An Xanthomonas citri pathogenicity gene, pthA, pleiotropically encodes gratuitous avirulence on nonhosts. Mol. Plant-Microbe Interact. 5:204-213.

Titarenko, E., Lopez-Solanilla, E., Garcia-Olmedo, F., and RodriguezPalenzuela, P. 1997. Mutants of Ralstonia (Pseudomonas) solanacearum sensitive to antimicrobial peptides are altered in their lipopolysaccharide structure and are avirulent in tobacco. J. Bacteriol. 179:66996704

Tung, S., and Kuo, T. 1999. Requirement for phosphoglucose isomerase of Xanthomonas campestris in pathogenesis of citrus canker. Appl. Environ. Microbiol. 65:5564-5570. 
Wang, J., So, B., Kim, J., Park, Y., Lee, B., and Kang, H. 2008. Genomewide identification of pathogenicity genes in Xanthomonas oryzae pv. oryzae by transposon mutagenesis. Plant Pathol. 57:1136-1145.

Wang, J. C., Temuujin, U., Kim, J. G., Park, Y. J., Lee, B. M., Choi, C. S. Silo-Suh, L. A., and Kang, H. W. 2010. Functional analysis and expressional regulation of $w x o E$ and $w x o F$ in lipopolysaccharide (lps) biosynthesis gene cluster I of Xanthomonas oryzae pv. oryzae. Physiol. Mol. Plant Pathol. 75:129-136.

Wang, P. G., Guo, H., Yi, W., and Song, J. K. 2008. Current understanding on biosynthesis of microbial polysaccharides. Curr. Top. Med. Chem. 8:141-151.

Way, S. S., Sallustio, S., Magliozzo, R. S., and Goldberg, M. B. 1999. Impact of either elevated or decreased levels of cytochrome bd expression on Shigella flexneri virulence. J. Bacteriol. 181:1229-1237.

Webb, C., Moreno, M., Wilmes-Riesenberg, M., Curtiss Iii, R., and Foster, J. W. 1999. Effects of DksA and ClpP protease on sigma S production and virulence in Salmonella typhimurium. Mol. Microbiol. 34:112-123.

Wengelnik, K., and Bonas, U. 1996. HrpXv, an AraC-type regulator, activates expression of five of the six loci in the hrp cluster of Xanthomonas campestris pv. vesicatoria. J. Bacteriol. 178:3462-3469.

Wengelnik, K., Van den Ackerveken, G., and Bonas, U. 1996. HrpG, a key hrp regulatory protein of Xanthomonas campestris pv. vesicatoria is homologous to two-component response regulators. Mol. Plant-Microbe Interact. 9:704-712.

Wiggerich, H.-G., and Puhler, A. 2000. The exbD2 gene as well as the iron-uptake genes tonB, exbB and exbD 1 of Xanthomonas campestris pv. campestris are essential for the induction of a hypersensitive response on pepper (Capsicum annuum). Microbiology 146:1053-1060.

Whitchurch, C. B., Alm, R. A., and Mattick, J. S. 1996. The alginate regu- lator $\mathrm{AlgR}$ and an associated sensor FimS are required for twitching motility in Pseudomonas aeruginosa. Proc. Natl. Acad. Sci. U.S.A. 93:9839-9843.

Whitchurch, C. B., Erova, T. E., Emery, J. A., Sargent, J. L., Harris, J. M., Semmler, A. B. T., Young, M. D., Mattick, J. S., and Wozniak, D. J. 2002. Phosphorylation of the Pseudomonas aeruginosa response regulator $\mathrm{AlgR}$ is essential for type IV fimbria-mediated twitching motility. J. Bacteriol. 184:4544-4554.

Yan, Q., and Wang, N. 2011. The ColR/ColS two-component system plays multiple roles in the pathogenicity of the citrus canker pathogen Xanthomonas citri subsp. citri. J. Bacteriol. 193:1590-1599.

Yoshida, K. I., Fujita, Y., and Ehrlich, S. D. 2000. An operon for a putative ATP-binding cassette transport system involved in acetoin utilization of Bacillus subtilis. J. Bacteriol. 182:5454.

Yu, H., Mudd, M., Boucher, J., Schurr, M., and Deretic, V. 1997. Identification of the $\operatorname{alg} Z$ gene upstream of the response regulator $\operatorname{alg} R$ and its participation in control of alginate production in Pseudomonas aeruginosa. J. Bacteriol. 179:187-193.

\section{AUTHOR-RECOMMENDED INTERNET RESOURCES}

J. Craing Venter Institute website: www.jcvi.org

KEGG:Kyoto Encyclopedia of Genes and Genomes website: www.genome.jp/kegg

The National Center for Biotechnology Information website: www.ncbi.nlm.nih.gov

European Molecular Biology Laboratory SMART database: smart.embl-heidelberg.de 